\title{
Investigating trade-offs in alternative catch-share systems: an individual-based bio-economic model applied to the Bay of Biscay sole fishery
}

\author{
Bellanger Manuel ${ }^{1,{ }^{*}}$, Macher Claire ${ }^{2}$, Merzéréaud Mathieu ${ }^{2}$, Guyader Olivier ${ }^{2}$, Le Grand Christelle ${ }^{3}$ \\ 1 Ifremer ,Centre de Bretagne, 113970, Technopole Brest-Iroise, Plouzane, France \\ 2 Ifremer ,Centre de Bretagne, 113970, Plouzane, France \\ ${ }^{3} \mathrm{~F} \& \mathrm{~S}$, Concarneau, France \\ *Corresponding author : Manuel Bellanger, email address : Manuel.Bellanger@ifremer.fr
}

\begin{abstract}
:
An individual-based bio-economic model (IAM) is presented and applied to the Bay of Biscay sole fishery to investigate alternative quota management systems from a multi-criteria perspective. For this study, the model integrates several institutional arrangements related to catch share management. The current French co-management system with non-transferability of quota is compared to an alternative ITQ system in a context of transition to maximum sustainable yield (MSY). Trade-offs between ecological and socio-economic impacts are highlighted and the effectiveness of governance scenarios is discussed in regard to the challenge of capacity adjustment. Results emphasize that the introduction of ITQ is expected to reduce by $40 \%$ the number of vessels in the fishery. While effectively mitigating the economic impacts of the transition phase to MSY, ITQs are also expected to significantly increase the fishing effort by trawlers, which may cause ecological concerns. The scenarios tested also include the simulation of a decommissioning scheme where subsequent decommissioned vessels are significantly different from the vessels that would lease out their quotas in an ITQ system, resulting in differentiated ecological and socio-economic impacts between scenarios.
\end{abstract}

Keywords: Bio-economic model, quota management systems, catch shares, institutional design, fisheries governance 


\section{Introduction}

Acknowledging the increase of anthropic pressure on fishery resources and the weaknesses of fisheries management solely based on conservation measures, scholars and public authorities now widely recognize that rights-based approaches are desirable for providing fishermen with appropriate incentives for stewardship and sustainability (Grafton et al. 2006; OECD 2006; Hilborn 2007; Allison et al. 2012). Catch share systems, in which individual fishermen, vessels, or producer organizations (POs) receive a fixed percentage of a yearly total allowable catch (TAC), are the dominant form of rights-based management institutions (Chu 2009; Jardine and Sanchirico 2012).

While experience on implementation of catch shares in a variety of biological, technological, and institutional settings has accumulated (Costello et al. 2008; Birkenbach et al. 2017), the literature on the development of integrated assessments of different catch share designs across the ecological, economic and social dimensions remains limited, despite this being increasingly demanded for informing fisheries management decisions (Péreau et al. 2012; Thébaud et al. 2012; Fulton et al. 2014).

Evaluations of potential fisheries management measures are traditionally based on simulations provided by integrated ecological-economic fisheries models that support policy decision making (Prellezo et al. 2012; Nielsen et al. 2017). These models have been used to forecast and compare the implications at aggregated fleet level of different options such as transition to the maximum sustainable yield (MSY), maximum economic yield (MEY) (Guillen et al. 2013; Merino et al. 2014; STECF 2015), or analyse trade-offs between management objectives (Mardle et al., 2002). Management evaluations have also considered impacts of selective devices (Macher et al. 2008; Raveau et al. 2012), management plans (STECF 2015) and introduction of individual transferable quotas (ITQs) (Marchal et al. 2011). Impact assessments based on bio-economic models have also included the management strategy evaluation (MSE) approach (e.g. Holland 2010; Bunnefeld et al. 2011; Ives et al. 2013; Fulton et al. 2014; Punt et al. 2016) where uncertainty associated with the 
observation and implementation of a TAC is traditionally well represented. However, MSEs generally do not explicitly take into account catch share management systems and disaggregated constraints at the individual producer level despite their influence on producers' strategies. Therefore, modelling frameworks that integrate interactions between resources, uses and governance mechanisms are needed for the simulation analysis of policy issues (Hopkins et al. 2012; Mongruel et al. 2013). The analysis should highlight trade-offs between management objectives and compare options against one another and against the baseline, thereby providing political decision-makers more complete information to aid with the decision process (Murillas-Maza and Andres 2016; Malvarosa et al. 2015).

This paper presents an individual-based bio-economic simulation model (the IAM model) that was developed to explore the impacts of catch share management systems from a multi-criteria perspective including the ecological, economic and social dimensions. It is applied to the Bay of Biscay common sole (Solea solea) fishery, which is a high-value commercial fishery and one of the first fisheries where individual quotas were implemented in France. The model explicitly represents quota management mechanisms according to existing institutional arrangements in the French comanagement system based on POs and a potential alternative ITQ system. This is the first study to present a model for fisheries socio-ecosystems that integrates such institutional arrangements and their interactions with the constraints and strategies of producers at the vessel level, which is critical to better account for the influence of governance systems in the impact assessment of management options. Therefore, this study contributes to research on bio-economic modelling by demonstrating the feasibility and relevance of adding institutional arrangements to a previously developed bioeconomic model to address sustainability measures and trade-offs. The approach also contributes to the literature on assessing different catch share designs by showing the power of an integrated analysis for undertaking management evaluation across the ecological, economic and social dimensions. 
The development of such an integrated modelling approach is particularly relevant to address catch share designs in Europe where advantages or disadvantages of ITQ-based national fishing quota markets compared to alternative PO-based quota co-management systems have been extensively debated in the context of the last reform of the common fisheries policy (CFP) (Coelho et al. 2011; Van Hoof 2013). In France, a PO-based catch share system was effectively implemented in 2006 in a context of global overcapacity of fishing fleets and increasing constraints on fishing opportunities. This system is characterized by a historical rights pooling mechanism organized at the PO level and by the fact that individual quota allocations are non-transferable (Larabi et al. 2013). In addition, policies for adjusting fleet capacity have relied on limited entry and public-aided decommissioning schemes (Quillérou and Guyader 2012). However, the European Commission identified heavy subsidies as one of the main problems of the CFP and thus tends to promote the use of ITQs rather than public-aided decommissioning schemes to achieve necessary reduction of fleet capacity (CEC 2009). The introduction of ITQs has been mostly rejected by French stakeholders during the discussions over the last reform of the CFP (Frangoudes and Bellanger 2017). France eventually took position against the generalization of ITQs (Gouvernement Français 2009; p.29) and supported a comanagement system in which POs are responsible for allocating quotas among their members. However, a report by the national competition authority (Autorite de la concurrence 2015) proposing ITQs as a potential solution to identified failures of the current system reopened the debate.

While POs effectively play a major role in catch share management in many EU member states (Aranda and Murillas 2015; Le Floc'h et al. 2015), existing models of EU fisheries do not incorporate quota management mechanisms as instigated at the PO level. As a result, they do not model the impacts such governance modes have on producer behaviours and bio-economic performances while considering multiple and potentially conflicting management objectives. As such, they fail in providing a good understanding of the complexities in PO-based co-management systems that is required for an adequate comparison with other governance systems based on market mechanisms. 
A means of overcoming this drawback is to develop innovative bio-economic tools that include the core processes of catch share management so as to augment the management model and the harvest control rule (HCR) implementation components of the typical MSE loop (Holland 2010; Bunnefeld et al. 2011; Punt et al. 2016).

\section{The common sole fishery in the Bay of Biscay}

The Bay of Biscay common sole fishery (ICES divisions VIIlab) is one of the most important fisheries in France. In 2014, it represented more than 360 vessels, 1200 fishermen and total gross revenue of 157 million euros. The fishery is managed by a Total Allowable Catch (TAC) decided at the European level, of which $91 \%$ is allocated to French fleets and $9 \%$ is allocated to Belgium beam trawlers. According to a typology that was specifically developed to study the Bay of Biscay demersal fisheries (Macher et al. 2011), the French sole fishery is mainly composed of the following fleet segments: specialized Nephrops trawlers, non-specialized Nephrops trawlers, mixed bottom trawlers, pelagic trawlers, mixed netters and sole netters (Table 1). In addition to the TAC, the management of the fishery also includes a total gross tonnage limit and a special fishing permit regulation so that aggregate capacity cannot increase and must decrease along with vessels' State-aided permanent cessation of activity (EC 2006). In other words, fishery exits funded with public money are used to reduce the fleet capacity (Quillérou and Guyader 2012). Consequently, decommissioning schemes implemented over the last decade on so-called sensitive fisheries, including sole, have largely contributed to the decrease of $26 \%$ of vessels landing more than one ton of sole between 2006 and 2014. On top of direct aid schemes, the industry also benefits from the overall exemption from fuel taxes, considered as indirect subsidies and increasingly criticized given the need to reduce greenhouse gas emissions (CEC 2009; Borrello et al. 2013).

Following high fishing mortalities on sole and risks of collapse in the 2000 's, a CFP management plan was implemented in 2002. The first step of the plan was to recover the fish stock to precautionary 
121 biomass limit $\left(B_{p a}=13000\right.$ tons). This objective was achieved in 2008. The second step was to define

122 multiannual management objectives based on the Johannesburg international objective of achieving

123 MSY by 2015 (UN 2002), and at the latest by 2020. In accordance with the CFP reform, management

124 plans should be implemented within a multispecies context where multiple stocks are jointly

125 exploited (Article 24 of Regulation (EU) No 1380/2013), which is yet to be enacted for the Bay of

126 Biscay sole management plan. The spawning stock biomass (SBB) peaked in $2009(15,919$ t.) and

127 decreased afterwards $(12,700 \mathrm{t}$. in 2014) due to the combination of poor recruitment of juveniles and

128 increased fishing mortality (ICES 2015). The current level of SSB is therefore well below the level of

129 biomass $B_{M S Y}$ needed to produce the maximum sustainable yield, $B_{M S Y}=28,800 t$.

130 
Table 1: Description of French fleet-length segments involved in the Bay of Biscay sole fishery in 2014. "Specialized Nephrops trawlers" and "Non-specialized Nephrops trawlers" are bottom trawlers targeting Nephrops (Nephrops norvegicus) more and less than 8 months per year, respectively. "Mixed bottom trawlers" are bottom trawlers that do not specifically target Nephrops. "Pelagic trawlers" dominantly use trawls that have no contact with the sea bed. "Mixed netters" catch a mix of species using gill nets. "Sole netters" target sole using trammel nets.

\begin{tabular}{|c|c|c|c|c|c|c|c|}
\hline Fleet & $\begin{array}{l}\text { Length } \\
\text { category }\end{array}$ & $\begin{array}{c}\text { Number } \\
\text { of } \\
\text { vessels }\end{array}$ & $\begin{array}{c}\text { Mean } \\
\text { crew per } \\
\text { vessel }\end{array}$ & $\begin{array}{c}\text { Mean } \\
\text { number of } \\
\text { days at sea } \\
\text { per vessel }\end{array}$ & $\begin{array}{c}\text { Mean number } \\
\text { of days at sea } \\
\text { on métier sole } \\
\text { per vessel }\end{array}$ & $\begin{array}{l}\text { Total } \\
\text { landings } \\
\text { of sole } \\
\text { (tons) }\end{array}$ & $\begin{array}{l}\text { Mean gross } \\
\text { value of } \\
\text { landings per } \\
\text { vessel }(k €)\end{array}$ \\
\hline \multirow{2}{*}{$\begin{array}{l}\text { Specialized } \\
\text { Nephrops } \\
\text { trawlers }\end{array}$} & $0-12 \mathrm{~m}$ & 14 & 2.2 & 174.8 & 14.1 & 28.2 & 260.9 \\
\hline & $12-24 \mathrm{~m}$ & 40 & 3.4 & 168.5 & 10.0 & 243.3 & 601.5 \\
\hline \multirow{3}{*}{$\begin{array}{l}\text { Non- } \\
\text { specialized } \\
\text { Nephrops } \\
\text { trawlers }\end{array}$} & $0-12 \mathrm{~m}$ & 3 & 2.0 & 147.7 & 52.0 & 11.7 & 235.2 \\
\hline & $12-18 m$ & 18 & 3.6 & 99.3 & 37.1 & 187.5 & 624.4 \\
\hline & $18-24 \mathrm{~m}$ & 8 & 4.7 & 104.8 & 31.8 & 92.4 & 869.0 \\
\hline \multirow{4}{*}{$\begin{array}{l}\text { Mixed } \\
\text { bottom } \\
\text { trawlers }\end{array}$} & $0-10 \mathrm{~m}$ & 20 & 1.4 & 128.2 & 62.5 & 54.3 & 120.5 \\
\hline & $10-12 \mathrm{~m}$ & 60 & 2.2 & 151.1 & 48.8 & 206.2 & 249.3 \\
\hline & $12-18 m$ & 22 & 3.3 & 90.4 & 28.4 & 147.1 & 502.8 \\
\hline & $18-24 m$ & 5 & 4.8 & 70.0 & 30.6 & 41.5 & 655.3 \\
\hline \multirow{3}{*}{$\begin{array}{l}\text { Pelagic } \\
\text { trawlers }\end{array}$} & $0-10 \mathrm{~m}$ & 4 & 2.7 & 175.8 & 24.2 & 10.6 & 390.1 \\
\hline & $10-18 \mathrm{~m}$ & 6 & 4.3 & 162.3 & 20.3 & 17.2 & 670.4 \\
\hline & $18-24 \mathrm{~m}$ & 8 & 5.3 & 113.2 & 3.5 & 17.1 & 1025.5 \\
\hline \multirow{2}{*}{$\begin{array}{l}\text { Mixed } \\
\text { netters }\end{array}$} & $0-10 \mathrm{~m}$ & 16 & 1.6 & 133.9 & 63.1 & 22.2 & 91.1 \\
\hline & $10-18 m$ & 7 & 2.1 & 139.9 & 48.9 & 10.6 & 121.9 \\
\hline \multirow{4}{*}{ Sole netters } & $0-10 \mathrm{~m}$ & 14 & 2.2 & 178.4 & 104.9 & 61.2 & 205.6 \\
\hline & $10-12 \mathrm{~m}$ & 47 & 3.2 & 153.8 & 104.9 & 614.1 & 313.8 \\
\hline & $12-18 m$ & 39 & 4.5 & 112.9 & 61.7 & 1031.4 & 642.0 \\
\hline & $18-24 \mathrm{~m}$ & 21 & 6.1 & 52.2 & 26.5 & 773.6 & 841.0 \\
\hline
\end{tabular}

Source: DPMA-Ifremer Fisheries Information System (2015)

Management of quotas in France is operated by the administration (regulator) and the producer organizations (POs) with an increasing role of the POs in the last decade (Larabi et al. 2013). The POs are groups of harvesters that collectively hold rights to manage their members' fishing activities. PO membership is voluntary and a PO as an entity is somewhat geographically-relevant. In the current French catch share system, national quotas are divided into sub-quotas per PO based on the pooled historical rights (also known as track records) of the PO members. In 2006, a decree established that the reference years for the calculation of the share each PO is granted were the years 2001-2003 (JORF 2006). The historical rights of non-PO vessels remain in a common pool managed by the 
administration, effectively generating a race-for-fish among non-PO vessels. In 2014, there were six

147 POs involved in the Bay of Biscay sole fishery (Fig. 1) that accounted for $95 \%$ of the landings.

148 Furthermore, the number of vessels and fleet composition are very uneven across POs (see Table S1

149 in supplementary material).

150

151

152

153

154

155

156

157

158

159

160

161

162

163

164

165

166

167

168

169

170

Following increasing constraints on their Bay of Biscay sole sub-quotas compared to resource availability, POs have developed various management systems including individual quotas, each PO being free to determine their own rules for quota allocation (Bellanger et al. 2016). Management rules are decided at the board of directors in each PO and can vary from year to year according to stock abundance and thus to risks of quota overruns or of unbalanced distribution of catch among seasons or among fleets. In general, POs implement allocation rules in line with two objectives: optimizing the use of the quota by PO members (catch-quota balancing, avoidance of in-season market congestion) and minimizing the monitoring costs and the risks of quota overruns. These allocation rules are based on criteria that vary among POs (e.g. historical landings, gear-based or equal-sharing rules). In 2014 , more than $70 \%$ of the sole landings were effectively subject to individual quotas (Guyader et al. 2014). Besides, POs typically require their members to detail their fishing activity plan before the start of each year so that each PO can internally use some reallocation arrangements as part of a collective management of fishing possibilities. Catch-quota balancing arrangements may also be operated by POs during the fishing season to ensure that quotas of target species are fully exploited.

In France, marketed transfers of historical rights or quota trades between producers are not allowed (JORF 1997), not even within POs. More specifically, a PO can reallocate quota from one individual to another within the PO, but this can only be a collective decision at the PO level. Thus, a transfer of allocation cannot be done simply with a mutual agreement between two fishermen and, in any case, cannot involve a monetary transaction. However, vessels can be transferred, and there exists a certain degree of flexibility in the management of historical rights (Larabi et al. 2013). Over time, 
171

172 fishery exits and vessel sells from one PO to another. These reserves of rights are redistributed 173 decision-making responsibilities in terms of managing their sub-quotas.

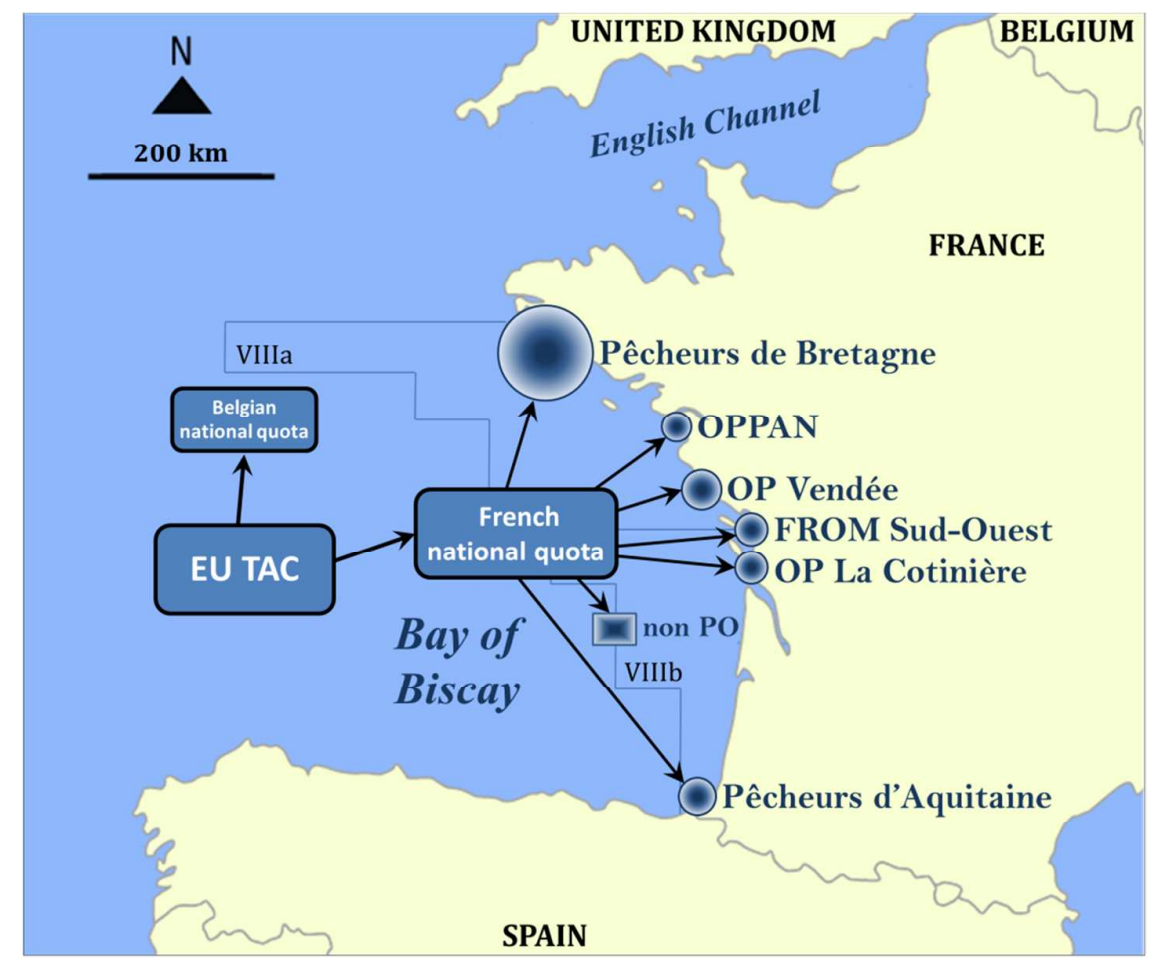

Figure 1. Map of the Producer Organizations (POs) in the Bay of Biscay in 2014 and distribution of the common sole (Solea solea) total allowable catch (TAC) and national quota between POs/non-PO commonpool. Circle size is scaled to the number of vessels operating in the PO ( $\min =93$, $\max =795)$. Map data (C2005 Wikipedia CC BY-SA 3.0.

\section{Bio-economic modelling for governance scenarios comparison}

The bio-economic model IAM (Impact Assessment Model for fisheries management) is used to 
187 Team 2017) for input and output processing (Merzereaud et al. 2011). The model consists of the 188 coupling of an operating model with a management procedure (Figure 2). The operating model 189 classically represents the biological dynamics of fish stocks and the harvest dynamics. It is age 190 structured to best apprehend the impacts of heterogeneous fleet selectivity on stock dynamics. It 191 also distinguishes multiple metiers (i.e., groups of fishing operations targeting a similar assemblage of 192 species, using similar gear, during the same period of the year and/or within the same area and 193 which are characterized by a similar exploitation pattern; see European Commission Decision 194 2010/93/EU, Appendix I Chapter 1, p.9) to account for the heterogeneity of the fishing practices 195 among fleets and vessels, which can operate multiple metiers during the course of a fishing season 196 (Ulrich et al. 2012). As compared to previous studies that used the IAM model (Macher et al. 2008; 197 Raveau et al. 2012; Guillen et al. 2013, 2015), the version of the model presented in this paper has 198 been augmented in a number of ways: (1) the model is vessel-based whereas previous versions were 199 fleet-based, (2) the short-term behavior module dictating individual efforts and catches per metier 200 now includes effort allocation dynamics driven by a combination of tradition and economic factors, 201 (3) a long-term behavior module that determines the adjustment of fleet capacity based on the 202 outputs of the economic module was developed to account for investment decisions, and (4) the management procedure now integrates several institutional arrangements related to catch share management. As opposed to most bio-economic fisheries models used for impact assessment (Nielsen et al. 2017), here the management procedure is not limited to a simple harvest control rule. It includes individual quota allocations following the quota pooling and reallocation mechanism operated by POs. It also integrates a module that mimics the management of historical rights related to fishery exits. In addition, the simulation of a decommissioning scheme and the simulation an ITQ 209 lease market can optionally be activated in the management procedure.

The combination of the operating model with the management procedure enables the simulation of the constraints and behaviour of fishermen at the individual level and their interactions through 
212 quota market and fish stocks. The model can be used to evaluate the impacts of various

213 management options and investigate the trade-offs between ecological, economic and social

214 objectives. The model considers the following dimensions: species $s$, age group $a$, fleet $f$, metier $m$,

215 vessel $i$, and year $t$.

216 A typical time step starts with the distribution of catch share from the TAC to national quotas, to PO

217 sub-quotas, to individual quotas, including allocations according to PO internal rules. For each vessel,

218 the short-term behaviour model dynamically distributes fishing effort across metiers, with a feedback

219 loop considering potential PO reallocations if the anticipated individual quota surplus is positive. Under the hypothesis of full exploitation of PO sub-quotas for a given species, multiple iterations of this loop (PO reallocations, individual quotas, short-term behaviour model) may be necessary until individual quota surplus is null for all vessels. Then the core components of the bio-economic model determine catches, stock dynamics, and economic variables. At the end of the time step, the long-term behaviour model dictates vessel entry/exit decisions and is linked to a historical rights management module that endogenously influences the distribution of catch shares for the next time step. While the essential features of the model relevant to the current study are summarized below, detailed equations are fully reproduced in online supplementary material. 


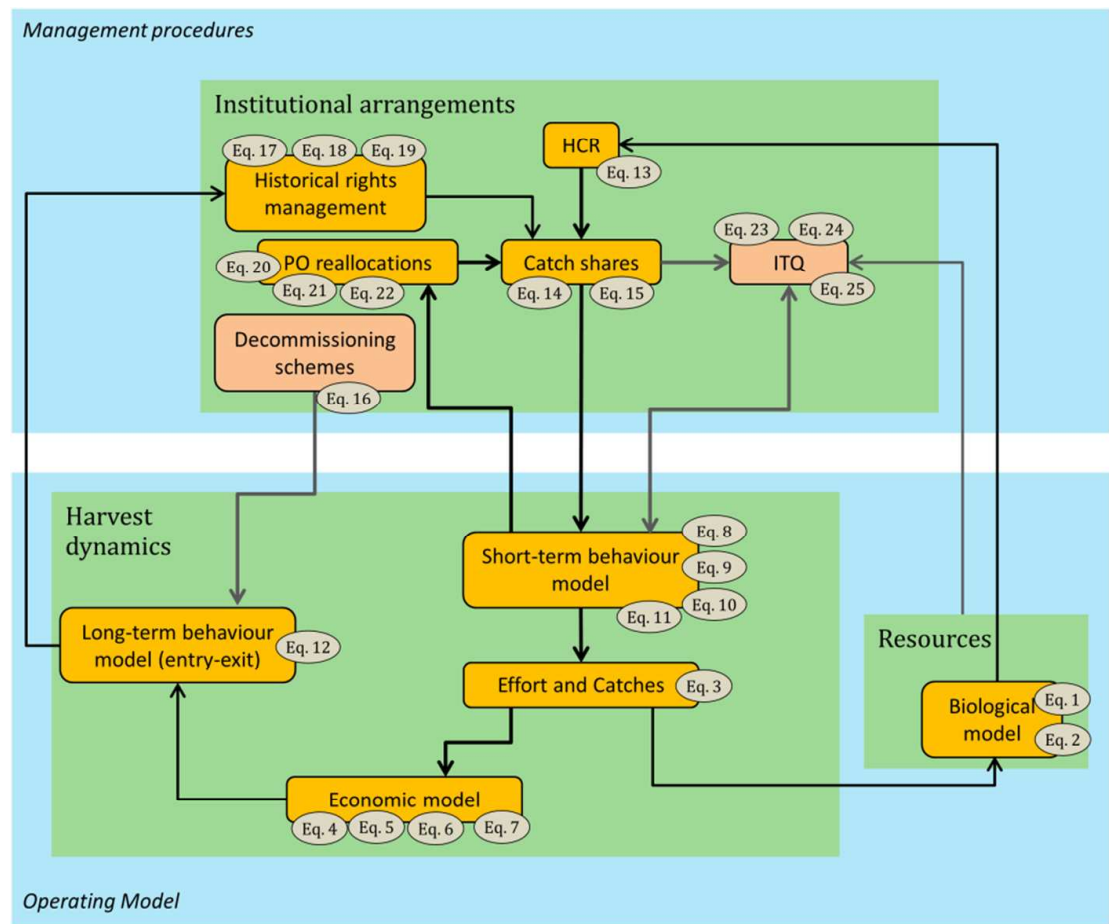

229

230

231

232

233

234

Fig. 2: Flowchart of the main processes run at each step of the model. Decommissioning schemes and individual transferable quotas (ITQ) can be (dis)activated as scenario. Equation numbers refer to equations included in this manuscript. HCR, harvest control rule; PO, producer organization.

\section{Resources}

\section{Biological model}

The stock dynamics of species $s$ are age structured to account for a variety of exploitation patterns by age and by vessel. It follows the Beverton and Holt (1957) equations:

$$
N_{s, a+1, t+1}=N_{s, a, t} \cdot e^{-Z_{s, a, t}}
$$

with:

$N_{s, a, t}:$ the number of individuals of species $s$ of age $a$ in year $t$

$Z_{s, a, t}:$ the total mortality, equal to the sum of natural mortality $M_{s, a, t}$ and fishing mortality $F_{s, a, t}$

The spawning stock biomass (SSB) is given by: 


$$
S S B_{s, t}=\sum_{a} \operatorname{Mat}_{s, a} \cdot N_{s, a, t} \cdot w_{s, a}
$$

242

244

245

246

247

248

250

251

252

253

254

255

256

257

258

259

260

with:

$w_{s, a}$ : the mean weight at age $a$ in the stock, assumed to be constant over the simulation period $M a t_{s, a}:$ the proportion of mature individuals at age $a$.

In line with ICES methodology (ICES 2015), the recruitment is assumed to be constant over the simulation period for this study.

\section{Harvest dynamics}

\section{Effort and catches}

Landings of species $s$, by vessel $i$ and metier $m, L_{i, s, m, t}$, are calculated using the Baranov equation:

$$
L_{i, s, m, t}=\sum_{a} \frac{F_{i, s, a, m, t}}{Z_{s, a, t}} \cdot N_{s, a, t} \cdot\left(1-e^{\left.-Z_{s, a, t}\right)}\right.
$$

where the fishing mortality $F_{i, s, a, m, t}$ of species $s$ by age, vessel, and metier is calculated as the product of a catchability coefficient $q_{i, s, a, m, t}$ and the effort $E_{i, m, t}$, the catchability coefficients being computed according to the initial effort and catch per metier of each vessel and the initial fishing mortality per age to account for particular selectivity profiles at the vessel level (Macher et al. 2008). Additionally, $F_{i, s, a, m, t}$ can be corrected by a discard factor and $Z_{s, a, t}$ accounts for discard survival rates. We see from eq. 3 that $L_{i, s, m, t}$ depends not only on the individual fishing mortality but also on the total mortality so that agents effectively interact through stock externalities.

\section{Economic model}

The gross value of landings by vessel and metier is calculated from the landings by species and metier, the ex-vessel price $p_{s, f, m}$ of species $s$ (assumed to be constant by fleet*metier), and a gross revenue of other "non-modeled" species by metier assumed to be constant by unit of effort 
$261\left(G V L_{\text {other,m }}\right)$ as in Raveau et al. (2012) and Gourguet et al. (2013). The total gross value of landings of $262 i_{f}$ (the vessel $i$ belonging to the fleet $f$ ) is thus the sum of the gross value of landings by metier:

$$
G V L_{i_{f}, t}=\sum_{m}\left(\sum_{s} p_{s, f, m} \cdot L_{i_{f}, m, s, t}+G V L_{o t h e r, m}\right)
$$

263 Denoting $c s h r_{i_{f}}$ the crew share of the gross revenue after deduction of variable costs, the crew costs $264\left(\operatorname{Crrew}_{i_{f}, t}\right)$ and the vessel gross operating surplus $\left(\pi_{i_{f}, t}\right)$ are then calculated as follows:

$$
\begin{gathered}
\operatorname{Ccrew}_{i_{f}, t}=\operatorname{cshr}_{i_{f} \cdot}\left(G V L_{i_{f}, t}-\sum_{m} \operatorname{CvarUE}_{i_{f}, m} \cdot E_{i_{f}, m, t}\right) \\
\pi_{i_{f}, t}=\left(1-\operatorname{cshr}_{i_{f}}\right) \cdot\left(G V L_{i_{f}, t}-\sum_{m} \operatorname{CvarUE}_{i_{f}, m} \cdot E_{i_{f}, m, t}\right)-C f i x_{i_{f}, t}
\end{gathered}
$$

265

266

267

268

269

270

271

272

273

274

275

with $\operatorname{CvarUE} E_{i_{f}, m}$ the variable costs (including fuel costs) per unit of effort by metier and $C$ fix $i_{i_{f}, t}$ the fixed costs. The variable costs are considered linearly dependent on the fishing effort (data analyses of the variable costs have been conducted on different samples to estimate variable costs as quadratic functions of the effort as suggested by Clark (2006) and used in Péreau et al. (2012); however, variable costs were found to be proportional of the effort in most cases).

The net present value of the net profit at time horizon $T$, considering a discount rate $r$, is then computed as the sum of discounted net profits over the discounting period:

$$
N P V_{i_{f}, t_{0}}^{(T)}=\sum_{t=t_{0}}^{T} \frac{1}{(1+r)^{\left(t-t_{0}\right)}} \cdot\left(\pi_{i_{f}, t}-\operatorname{Ccap}_{i_{f}, t}\right)
$$

with $\operatorname{Ccap}_{i_{f}, t}$ the cost of capital depreciation.

\section{Short-term behaviour model}

The model simulates the short-term dynamics of fishing activity in terms of individual effort per metier. The modelling of fishermen' behaviour often considers the choice of metier as driven by a 
combination of tradition and economic factors (Soulié and Thébaud 2006; Marchal et al. 2009, 2011).

277 Besides, quota availability of target species $Q_{i, s, t+1}$ and individual maximum effort $E_{i, \max }$ constrain

278 the choice of fishermen. The short-term behaviour model that we developed combines an effort 279 allocation module and an effort determination module that are built in endogenously. The effort allocation module distributes the individual efforts per metier according to the short-term anticipated marginal profits and to the efforts observed during the previous year. The effort determination module adjusts individual efforts with the production function (eq. 3) with constraints on landings $\left(L_{i, s, t+1} \leq Q_{i, s, t+1}\right)$ and on maximum effort.

In order to keep the description of the model simple, let us consider the case where there are two metiers (Met 1 and Met2), and one species $(s)$ subject to binding quotas. We further suppose that $s$ is a target species for Met2 (so that individual landings constraints apply) whereas it is a bycatch for Met1. Let $\alpha$ and $1-\alpha$ be the relative weight given to anticipated profit and traditions, respectively. We also define $\hat{E}_{i, m, t+1}^{M A X}$ the anticipated effort on metier $m$ if $100 \%$ of the individual allocation $Q_{i, s, t+1}$ is used on metier $m$ :

$$
\hat{E}_{i, m, t+1}^{M A X}=Q_{i, s, t+1} \cdot \frac{E_{i, m, t}}{L_{i, s, m, t}}
$$

For each vessel $i$ :

$$
E_{i, m=M e t 1, t+1}:=(1-\alpha) . E_{i, m=M e t 1, t}
$$

$$
E_{i, m=M e t 1, t+1}:=E_{i, m=M e t 1, t}+\alpha \cdot E_{i, m=M e t 2, t}
$$

where $\pi_{i, m, t}=\left(1-c s h r_{i}\right) \cdot\left(\sum_{s} p_{s, f, m} \cdot L_{i, m, s, t}+G V L_{o t h e r, m}\right)$. 
during the previous year if the Met 1 is more profitable (eq. 10). If $\alpha=0$, the effort on the Met 1 remains constant throughout the simulation.

Effort allocation on Met 1 imposes a constraint of available effort for Met2 $\left(E_{i, m=M e t 2, t+1} \leq\right.$ $\left.E_{i, \max }-E_{i, m=M e t 1, t+1}\right)$. The determination of individual effort for Met2 thus depends on the profittraditions weighting (eq. 9-10) via the maximum effort constraint but also on a landings constraint 301 because Met 2 targets a species that is subject to binding quota. $E_{i, m=M e t 2, t+1}$ is therefore such that:

$$
\begin{cases}L_{i, s, m=M e t 2, t+1}=Q_{i, s, t+1}-L_{i, s, m=M e t 1, t+1} & \text { if } E_{i, m=M e t 2, t+1} \leq E_{i, \max }-E_{i, m=M e t 1, t+1} \\ E_{i, m=M e t 2, t+1}:=E_{i, \max }-E_{i, m=M e t 1, t+1} & \text { otherwise }\end{cases}
$$

302

where $L_{i, s, m, t+1}$ is determined according to the Baranov production function (eq. 3). Eq. 11 is a constrained optimization problem and the solution $E_{i, m=M e t 2, t+1}$ (that depends on the total mortality $\left.Z_{s, a, t+1}\right)$ is simultaneously found for all $i$ with a convergent iterative process similar to the method of Lagrange multiplier.

\section{Long-term behaviour model}

The long-term fleet dynamics relate to investment and disinvestment decisions that affect the capacity of the fleets. In the model, we consider that vessel entry/exit decisions depend on profitability and potential imperfect malleability of capital as suggested by the theory (Clark et al. 1979). Previous revenues are used as a proxy of potential earnings. An investment module representing fleet-level entry decisions, similar to the one described in Garcia et al. (2012), has been developed, but was excluded for this study as the CFP management plan for the Bay of Biscay sole fishery prevents increasing capacity. For fishery exits, the model represents disinvestment decisions at the vessel level and distinguishes fishery exits without public aids from fishery exits supported by public aids as part of a decommissioning scheme (see Eq. 16). Without public aids, $i_{f}$ exits the fishery before the start of step $t+1$ if: 


$$
\frac{G V L_{i_{f}, t}-C f i x_{i_{f}, t}-\sum_{m} \operatorname{CvarU} E_{i_{f}, m} \cdot E_{i_{f}, m, t}-\operatorname{Ccrew}_{i_{f}, t}}{G V L_{i_{f}, t}}<-\omega_{i_{f}}
$$

317 where $\omega_{i} \in[0,1]$ is a parameter that represents capital malleability for the vessel $i$, i.e. whether 318 investment is reversible in terms of vessel resale value for capital when exiting the fishery (with $319 \omega_{i}=0$ corresponding to perfect malleability).

\section{Institutional arrangements}

\section{Harvest control rule}

The TAC can be either exogenously given, or dynamically modified based on the output data generated by the biological model as part of the management procedure. One such decision rule that we modelled is the determination of a TAC such that the expected fishing mortality is consistent with achieving MSY (i.e. stock exploitation at $F_{M S Y}$ ) as assumed in the ICES advice procedure. Using the same variable notations as in eq. $1-3$, the $\mathrm{TAC}_{\mathrm{MSY}}$ is computed as follows:

$$
T A C_{s, t}=\sum_{a} \frac{F_{s, a, t-1} \times \frac{F_{M S Y}}{F_{S, t-1}}}{F_{s, a, t-1} \times \frac{F_{M S Y}}{F_{s, t-1}}+M_{s, a, t}} \cdot N_{s, a, t} \cdot\left(1-e^{-\left(F_{s, a, t-1} \times \frac{F_{M S Y}}{F_{s, t-1}}+M_{s, a, t}\right)}\right)
$$

327 where $F_{s, t-1}=\sum_{a} F_{s, a, t-1}$.

\section{Catch shares}

The 'institutional arrangements' sub-model makes explicit the distribution of the TAC among member states, the allocation of collective sub-quotas to POs and individual allocations to producers. Let FLEET be the entire fleet, i.e. the set of all vessels $i$. For a given Total Allowable Catch in year $t$ $\left(T A C_{s, t}\right)$, the sub-quota $Q_{j, s, t}$ allocated to the producer organization $j$, is given by:

$$
Q_{j, s, t}=\frac{\sum_{i \in j} \sum_{\tau=2001}^{\tau=2003} L_{i, s, \tau}}{\sum_{i \in F L E E T} \sum_{\tau=2001}^{\tau=2003} L_{i, s, \tau}} \times T A C_{s, t}
$$

with $L_{i, s, \tau}$ the historical landings of vessel $i$ in year $\tau$. 
Initial allocation of catch share to producers is then:

$$
Q_{i, s, t}=\phi_{i, s, t}^{j} \times Q_{j, s, t}, \forall i \in j, \forall j \in F L E E T
$$

335

336

337

338

339

340

341

342

344

345

346

347

348

349

350

where $\phi_{i, s, t}^{j}$ is the allocation key used by the producer organization $j, \sum_{i \in j} \phi_{i, s, t}^{j}=1$.

\section{Decommissioning schemes}

The simulation of a decommissioning scheme can be considered as part of the management procedure. In that case, the decision rule implemented is similar to the one presented in Guyader et al. (2004). Suppose a vessel $i$ is eligible to a decommissioning premium Prem $_{i, t}$. It is assumed that the decision at the individual level depends on the net present value of the gross operating surplus at year horizon $T$ and the discounted replacement value of the vessel. Thus, on condition of eligibility to a decommissioning scheme, $i_{f}$ exits the fishery before the start of step $t+1$ if:

$$
\operatorname{Prem}_{i_{f}, t}>N P V_{i_{f}, t}^{(T)}+\frac{\operatorname{Repv}_{i_{f}, T}}{(1+r)^{(T-t)}}
$$

with $\operatorname{Repv_{i},T}$ the replacement value of vessel $i_{f}$ that can be estimated according to the PIM method (IREPA Onlus coordinator 2006).

\section{Historical rights management}

In France, although historical rights are non-tradeable among producers, the historical landings track records attached to scrapped vessels can be transferred to some reserves of historical rights that were created at the national and PO levels alongside decommissioning schemes. These reserves are critical for quota management as they increase the POs' collective quotas, and the benefits of decommissioning schemes can be heterogeneous if the proportion of eligible vessels varies across POs. The details of these arrangements (e.g. the shares of historical rights attached to the scrapped vessels transferred to the national and the PO reserves according to whether decommissioning is associated with premiums) are quite complex and have evolved over years (JORF 2014; see décret $n^{\circ}$ 

2014-1608 du 26 décembre 2014, articles R921-44 and R921-45 for current regulation). The mechanism describing the transfer of historical rights to reserves associated with the 356 decommissioning of vessel $i$, member of the $\mathrm{PO} j$, can be formalized in a generic manner as follows:

$$
\left[\begin{array}{c}
R s v_{j, s}^{\text {update }}:=R s v_{j, s}+P O s h r_{i} \cdot\left(\sum_{\tau=2001}^{\tau=2003} L_{i, s, \tau}\right) \\
R s v_{\text {nat }, s}^{\text {update }}:=R s v_{\text {nat }, s}+\operatorname{NATshr}_{i} \cdot\left(\sum_{\tau=2001}^{\tau=2003} L_{i, s, \tau}\right)
\end{array}\right.
$$

357 with

$358 R s v_{j, s}:$ the reserve of $\mathrm{PO} j$

359

360

$R s v_{\text {nat }, \text { }}:$ the national reserve

$\mathrm{POShr}_{i}$ : the share of historical rights transferred to the PO reserve

361

362

$N A T s h r_{i}$ : the share of historical rights transferred to the national reserve

363

$$
P O \operatorname{shr}_{i}+\operatorname{NATshr}_{i}=1, \forall i
$$

364 Then the historical landings of vessel $i$ are set to 0 and the vessel is considered as definitively decommissioned (i.e. it exits the fleet and the PO):

$$
\left[\begin{array}{rl}
L_{i, s, \tau}:=0, \tau \in & 2001,2002,2003 \\
F L E E T_{t+1} & :=F L E E T_{t} \backslash\{i\} \\
j_{t+1} & :=j_{t} \backslash\{i\}
\end{array}\right.
$$

where $j_{t}$ is the set of vessels that are member of the PO $j$ at time $t$. The sub-quota $Q_{j_{t}, s, t}$ defined in 367 eq. 14 then becomes:

$$
Q_{j, s, t+1}=\frac{\sum_{i \in j_{t+1}} \sum_{\tau=2001}^{\tau=2003} L_{i, s, \tau}+R s v_{j, s}}{\sum_{i \in F L E E T_{t+1}} \sum_{\tau=2001}^{\tau=2003} L_{i, s, \tau}+\sum_{j} R s v_{j, s}+R s v_{n a t, s}} \times T A C_{s, t+1}
$$


369 To ensure that quotas of target species are fully exploited, a reallocation mechanism within POs can

370 be considered when the anticipated individual quota consumption is less than $100 \%$. We denote by

$371 m=$ target the metier that targets the species $s$ managed with individual quotas $\left(E_{i, m=\text { target }, t}\right.$ is

372 thus the control variable that the model adjusts to try to obtain $L_{i, s, t}=Q_{i, s, t}$ ). Defining the landings

373 per unit of effort $L P U E_{i, s, m, t}$ as

$$
\operatorname{LPUE}_{i, s, m, t}=\frac{L_{i, s, m, t}}{E_{i, m, t}}
$$

374 and the anticipated individual quota surplus $Q_{i, s, t+1}^{\Delta}$ as

$$
\begin{aligned}
Q_{i, s, t+1}^{\Delta}=Q_{i, s, t+1} & -\sum_{m \neq \text { target }} E_{i, m, t+1} \cdot L P U E_{i, s, m, t} \\
& -\left(E_{i}^{M A X}-\sum_{m \neq \text { target }} E_{i, m, t+1}\right) \cdot L P U E_{i, s, m=\text { target }, t}
\end{aligned}
$$

375 the reallocation mechanism operates as follows: for each vessel $i$ of the PO $j$, if $Q_{i, s, t+1}^{\Delta}>0$ then

$$
\left[\begin{array}{c}
\forall \tilde{\imath} \in j_{t+1} \text { such that } Q_{\tilde{\imath}, s, t+1}^{\Delta} \leq 0, \quad Q_{\tilde{\imath}, s, t+1}^{\text {update }}:=Q_{\tilde{\imath}, s, t+1}+Q_{i, s, t+1}^{\Delta} \cdot \frac{Q_{\tilde{\imath}, s, t+1}}{\sum_{\tilde{\imath}} Q_{\tilde{\imath}, s, t+1}} \\
Q_{i, s, t+1}^{\text {update }}:=Q_{i, s, t+1}-Q_{i, s, t+1}^{\Delta}
\end{array}\right.
$$

376 where $Q_{i, t+1}^{\text {update }}$ is the new value of $Q_{i, t+1}$ after reallocation. Note that the variable $Q_{i, s, t+1}^{\Delta}$ is fixed by 377 eq. 21 and is not updated by the procedure defined with eq. 22 so that $\left\{i \in j_{t+1} \mid Q_{i, s, t+1}^{\Delta}>0\right\}$ and $378\left\{\tilde{\imath} \in j_{t+1} \mid Q_{\tilde{l}, s, t+1}^{\Delta} \leq 0\right\}$ are two distinct sets of vessels. This reallocation can be run after the 379 adjustment of effort by vessel on the other metiers (eq. 9-10) to ensure full exploitation of target species quotas.

Individual transferable quotas

382 The simulation of the ITQ lease market integrates the Baranov catch equation of the bio-economic model so that interactions among individual agents are taken into account via stock externalities. Let 
$384 Q_{i, s, t}$ be the initial quota of species $s$ allocated to vessel $i$. The quota lease market is described by the 385 following constrained optimization problem:

$\forall i$ determine $E_{i, m, t}^{*}$ such that

$$
\begin{gathered}
\pi_{i_{f}, t}^{I T Q}\left(E_{i, m, t}^{*}\right)=\max _{E} \pi_{i_{f}, t}^{I T Q}\left(E_{i, m, t}\right) \\
\text { subject to } \sum_{i} \sum_{m} L_{i, s, m, t}=\sum_{i} Q_{i, s, t}
\end{gathered}
$$

$387 \quad$ with

$$
\begin{aligned}
\pi_{i_{f}, t}^{I T Q}\left(E_{i, m, t}\right)=( & \left.-c s h r_{i_{f}}\right) \cdot \sum_{m}\left(\sum_{s} p_{s, f, m, t} \cdot L_{i, s, m, t}-\operatorname{CvarUE}_{i_{f}, m} \cdot E_{i, m, t}\right) \\
& -p_{s, t}^{\text {quota }} \cdot\left(\sum_{m} L_{i, s, m, t}-Q_{i, s, t}\right)-C f i x_{i_{f}, t}
\end{aligned}
$$

388 where the price of one unit of quota $p_{s, t}^{q u o t a}$ is unknown and must be adjusted such that supply and 389 demand coincide in a context of individual profit maximization. Since for each vessel the individual 390 effort needed to reach a given objective in terms of landings depends on the efforts of all the other 391 vessels (eq. 3), it is in fact a multi-dimensional problem whose complexity increases with the number 392 of vessels. To avoid the difficulties related to multi-dimensional solving, the problem can be 393 transformed into an iterative process involving successive one-dimensional optimizations and 394 convergent key factors correction. This transformation allows using standard linear programming 395 routines to efficiently find a solution. The convergence procedure used to determine $p_{s, t}^{q u o t a}$ under 396 constraints is:

$$
\begin{aligned}
& \quad p^{(0)}=p_{0} \\
& \forall k>0, \\
& \quad p^{(k)}=p^{(k-1)}+\lambda \cdot\left(\sum_{i} \sum_{m}\left(L_{i, s, m, t}(k)-Q_{i, s, t}(k)\right)\right) \\
& p_{s, t}^{q u o t a}=p^{(k)}, k \text { s.t. } p^{(k)}-p^{(k-1)}<\varepsilon_{1} \& \sum_{i} \sum_{m}\left(L_{i, s, m, t}(k)-Q_{i, s, t}(k)\right)<\varepsilon_{2}
\end{aligned}
$$


where $\lambda, \varepsilon_{1}, \varepsilon_{2}>0$ are set to ensure a balance between quick convergence and precision of estimation. The price of quota and the individual efforts can then be derived simultaneously with a nested iterative procedure aimed at achieving double convergence. As the costs and the production function are assumed linear, solutions are corner solutions for each individual vessel that will either lease in quota to be able to fish until its maximum effort or will lease out its own quota. If there are multiple metiers, a 'lease-out vessel' typically leases out the entire share of its quota not dedicated to metiers for which species $s$ is a bycatch, so that a share of the quota apportioned to cover bycatch may be retained for the vessel to maintain a fishing activity on a metier that does not target $s$.

\section{Scenarios for the impact assessment of alternative catch share systems}

Three distinct management scenarios for the Bay of Biscay sole fishery were analyzed according to a set of multi-criteria indicators using simulations performed with the bio-economic model integrating the 'institutional arrangements' sub-model. These scenarios were determined so as to reflect some of the potential options supported by different stakeholders. To make a meaningful comparison, the initial individual catch share allocations operated by POs are consistent across the three scenarios and are proportional to landings of reference. Common hypotheses across scenarios also include:

- Bay of Biscay sole TACs are set such that the stock is exploited at $F_{M S Y}$

- full exploitation of Bay of Biscay sole quotas (supported by the fact that landings have systematically reached the TAC in recent years)

- no restriction on landings of other species (no choke species preventing the exploitation of sole quotas)

- short-term fleet dynamics defined by eq. 8-10 that represents potential seasonal activity intensification 
- long-term fleet dynamics relating to disinvestment decisions defined by eq. 12 and the

\section{Quota co-management Decommissioning Scheme (DS) scenario}

In this second scenario, we consider a co-management catch-share system similar to the BA scenario (including the non-transferability of individual allocation and the quota reallocation mechanism) with the additional postulate that the State operates in year $t=t^{D S}$ a publicly funded decommissioning scheme (without constraint on funding availability) to reduce the fleet capacity. We assume that the decision of staying or decommissioning is instantaneous at the start of the year $t^{D S}$ (eq. 16). The transfer of historical rights associated to vessels decommissioning (eq. 17-19), typical of the French co-management system, is of particular importance in this scenario since it determines how the quotas of decommissioned vessels are redistributed among the remaining vessels.

\section{Individual Transferable Quotas (ITQ) scenario}

In this scenario, each individual vessel is granted a share of the TAC that can then be traded on a quota lease market (eq. 23-25). We make the assumption that the Bay of Biscay sole is the only 
443 species that can be traded. The aim of this management option is to address issues of excessive fleet

444 capacity with market instruments (as opposed to using public money like in the DS scenario) and 445 maximize the fleets' profitability in a context of transition to MSY.

\section{Parameters and model initialization}

447 The reference year used for parameterization is 2014 and the simulations were run over the period

$448 \quad 2015-2025$ for a selection of 359 individual vessels that have caught more than 1 ton of sole in the 449 Bay of Biscay in 2014. TACs were determined as follows:

450 cost per unit of effort and fixed cost structure were available for a sample of vessels in 2013 (see Table S19 in supplementary material for average cost structures by sub-fleet and length class) and were then estimated by vessel for 2014 according to their sub-fleet and length class (the sub-fleet 
Nephrops by commercial grade were assumed to be constant and were calculated on year 2014 for

467 each intersection of sub-fleet, length class, and metier.

As a simplifying assumption we consider that each vessel plans its fishing activities by choosing among two metiers:

- "sole metier", corresponding to the fishing activity that targets sole

- "other metier", corresponding to the fishing activity where sole is not targeted and considered a bycatch.

Fishing mortality by metier is parameterized at the vessel-trip level using a criterion that was specifically determined for the Bay of Biscay dermersal fisheries, defining a fishing trip as targeting sole when sole represents more than $6 \%$ of the trip landings in weight and Nephrops represents less than $10 \%$ (ICES 2015). Individual efforts on sole metier are control variables of the bio-economic model that can be endogenously determined to achieve a given fishing mortality. Individual efforts on other metier are initialized based on the reference year.

PO affiliations (membership) and historical landings were obtained with the actual database that was used for the French administration to determine the allocation of catch shares to POs. The distribution keys used by POs for the initial allocation of individual quotas to vessels are assumed proportional to the landings of reference $L_{i, s=s o l e, t=2014}$. Regarding the transfer of historical rights associated with fishery exits, we assume that the share transferred to the PO reserve is $P O s h r_{i}=1$ for all vessel $i$ that have PO membership whereas non-PO vessels are such that $N A T s h r_{i}=1$.

A number of empirical studies have estimated that traditions tend to prevail upon economic drivers in fishermen individual choices related to their fishing activity (Holland and Sutinen 1999; Marchal et al. 2009, 2013). In keeping with the empirical estimates that can be found in Marchal et al. (2013), we set the relative weights given to balance anticipated profit and traditions to $\alpha=0.2$ and $1-\alpha=0.8$ respectively, i.e. the individual effort on other metier can vary up to $\pm 20 \%$ at each step $t$. The capital malleability parameter $\omega_{i}$ is assumed equal to 0.05 for all $i$. As recommended by 
491 Lebègue et al. (2005) for the evaluation of public projects in France, a discount rate of $r=0.04$ is 492 assumed for the computation of the net present value (eq. 7) and disinvestment decisions (eq. 16).

493 For the parameters that are relevant to the DS scenario, we set $t^{D S}=2017$ and $\operatorname{Prem}_{i, t}$ is 494 calculated using the same method as in decommissioning schemes that have been implemented in 495 various fisheries in France over the last decade (e.g. see https://www.legifrance.gouv.fr/ 496 affichSarde.do?idSarde=SARDOBJT000007105189). The premium scale is reproduced in Table S20 497 (supplementary material). The time horizon considered in eq. 16 is $T=20$ years. 


\section{Multi-criteria indicators for impact assessment}

500 The impact assessment multi-criteria analysis aims at rating the different management options

501 proposed in terms of ecological, economic and social sustainability. The analysis that we carried out

502 follows the general prescriptions of the EU guidelines (EC 2009), and the selected criteria are inspired

503 by the impact assessment methodology developed in the framework of the European research

504 project SOCIOEC (Malvarosa et al. 2015) and applied in Bay of Biscay management plan evaluations

505 (STECF 2015). For each of the ecological, economic and social sustainability dimensions, the

506 assessment procedure consisted of the following steps: selection of a small set of relevant indicators;

507 description of the evolution of the situation under the baseline scenario; quantitative measure and

508 comparison of the relative effectiveness of alternative management scenarios using the baseline as

509 reference point. Long-term impacts were evaluated using the end year of the simulation period

510 (2025) and transition phase impacts were measured on the first year where the simulated TAC was

511 based on $F_{M S Y}(2017)$. Most of the selected indicators can be straightforwardly calculated from the

512 output of the model.

513 Alongside stock status and carbon footprint indicators, selected proxies for ecological sustainability

514 also include fishing effort and trawling energy effort. Although fishing effort may not be a relevant

515 proxy for impacts on habitats for all types of fisheries, fishing practices targeting sole or other

516 demersal fish (living on the seabed) have some impacts on the seabed such as the displacement and

517 suspension of bottom sediments, thus perturbing benthic habitats to some extent (Kaiser et al.

518 2003). In particular, trawling can cause physical impacts on the seabed and disturbance in benthic

519 ecosystems (Jennings et al. 2001; O'Neill and Ivanović 2016), which motivates the use of trawling

520 energy effort, measured as the engine power in kW multiplied by the fishing time of trawlers, as an

521 indicator for ecological impacts.

522 Criteria for economic impacts include the net present value of net profits and an indicator of

523 economic viability (Gourguet et al. 2016; Murillas-Maza and Andres 2016), measured as the 
524

525

526

527

528

529

530

531

532

533

534

535

536

537

538

539

540

541

542

543

544

545

546

547

proportion of vessels having a positive gross operating surplus. Additionally, the evolution of revenue inequality in the fishery was considered by means of the decomposability property of the Theil index that can be used to compute the contributions of different fleet segments to the total revenue inequality (see supplementary material for a detailed definition of the Theil index and its additive decomposability).

Social sustainability is evaluated with indicators related to employment and social acceptability. For the purpose of the analysis, employment hours are measured as the sum over all vessels in the fishery of the yearly number of hours at sea per metier and multiplied by average crew per metier. Variations in employment hours are identical to variations in full time equivalent (FTE) employment as those two proxies only differ by a scalar. Average yearly and hourly wages are used to evaluate acceptability. In addition, time at sea is used as a proxy for drudgery of work, which is supported by the fact that long working hours at sea generally induce sleep disturbance, increased fatigue causing more accidents, isolation from family, friends and social life, and long-term consequences for health (Allen et al. 2006; Høvdanum et al. 2014).

\section{Results}

\section{Evolution under the quota co-management baseline (BA) scenario}

The baseline co-management scenario toward MSY resulted in a limited decrease of the number of vessels (-4\% on the simulation period; see Fig. 3 ) and thus in the conservation of the fleet structure in general. In this case, fishery exits were disinvestment decisions due to negative profits and vessels that left were decommissioned without premium. This scenario achieved satisfactory ecological objectives in general including the rebuilding of the sole and Nephrops stocks (Fig. S2 in supplementary material) and the reduction of impact on habitats and carbon footprint. The total fishing effort first decreased by 31\% between 2014 and 2017 due to decreasing TACs, and then was approximately constant until 2025 while the TACs were in fact increasing, which means that SSB 
548 recovery induced higher landings per unit of effort (Fig. 5a). The total trawling energy effort 549 decreased by 33\% between 2014 and 2017, and then only slightly increased between 2017 and 2025 550 (+7\%) (Fig. 5b). Not surprisingly, the total fuel consumption followed an analogous path (Fig. S5 in 551 supplementary material).

552 From an economic sustainability perspective, the primary concern was the economic viability of the 553 fleet in a context of overcapacity and transition to MSY. The total gross operating surplus of the 554 fishery decreased by $27 \%$ between 2014 and 2017 due to decreasing TACs (Fig. 6a). The economic 555 viability of the fleet hit its lowest point in 2017 with $7 \%$ of vessels having a negative gross operating 556 surplus that year (Fig. 6b). The fleetwide gross operating surplus then increased between 2017 and 5572025 together with SSB recovery and increasing TACs. The cumulative net present value of fleetwide 558 net profits throughout the simulation period was 202 million $€$. The total economic inequality 559 between vessels slightly increased between 2014 and 2017 and was constant after (Figs. S8 and S9 in 560 supplementary material). The decomposition of the inequality by fleet (Fig. S9a) revealed that the 561 main contributors to the inequality increase between 2014 and 2017 were the Nephrops trawlers.

562 Employment hours first decreased by 32\% between 2014 and 2017 and then slightly increased 563 between 2017 and 2025 (+5\%) but remained significantly lower than their initial level (Fig. 7a). The 564 average time at sea followed a similar trajectory (Fig. 7c). Contrastingly, the average hourly wage per 565 crew increased from $18 € / \mathrm{h}$ to $28 € / \mathrm{h}$ over the simulation period (Fig. $7 \mathrm{~d}$ ) so that the average yearly 566 wage per crew in 2025 was greater than its 2014 level (+20\%) despite the reduction of the time at 567 sea. Therefore, these results suggested that the socio-economic benefits expected from MSY 568 exploitation were mostly directed to enhance wages rather than the number of jobs in the fishery. 569 Additionally, the salary increases appeared to be accompanied by a moderate augmentation of the 570 total inequality among yearly wage per crew (Fig. S10 in supplementary material). The 571 decomposition of this inequality by segments indicated that this was due to increased inequality 572 between fleets and more heterogeneous wages within the larger-scale vessels length classes (see Fig. 
573 S11 in supplementary material). Since most vessels remained active in this scenario, changes in fleet

574 composition and territorial impacts were minimal.

575 Trade-offs achieved under the quota co-management decommissioning scheme (DS)

576 scenario

577 In the DS scenario, the simulated decommissioning scheme resulted in the exit (with premium) of 61

578 vessels that were constituted of $12-18 \mathrm{~m}$ trawlers for the most part (Fig. 4a). In contrast, only a few

579 sole netters were expected to leave the fishery within this decommissioning scheme. As the

580 discounted replacement value of vessels at the end of the discounting period was not very significant

581 for most vessels, the main drivers of the individual decision to stay or leave were the net present

582 value of the expected gross operating surplus and the decommissioning premium.

583 Overall, the DS option performed better than the BA option on ecological indicators (Table 2).

584 Particularly, the total fishing effort and trawling energy effort were decreased $(-10 \%$ and $-16 \%$ in

585 2017, respectively). The DS scenario also achieved better economic efficiency than the baseline as

586 the net present value of profits over the whole simulation period was increased by $6 \%$ (Table 3 ). The

587 economic viability of the fleet was improved during the transition phase (+7\% in 2017). In addition,

588 the economic inequality was decreased $(-7 \%$ compared to the BA scenario in the year after the

589 application of the decommissioning scheme), this reduction being mostly associated to distributional

590 changes in the trawler fleets (Fig. S9c in supplementary material). This result can be explained by the

591 fact that the vessels that exited the fishery with a decommissioning premium were essentially vessels

592 with poor economic performances, so that the vessels that remained in the fleet were somewhat

593 more homogenous in terms of revenue.

594 Social impacts of the DS scenario included lower employment hours in the fishery than in the BA

595 scenario $(-10 \%)$ but higher average yearly wage $(+13 \%)$ (Table 4$)$. Wage inequality was also

596 marginally decreased, particularly within the mixed bottom trawlers fleet (Fig. S11c in supplementary 
material), as a result of the decommissioning scheme. Therefore, the effectiveness of the DS scenario

598 in the social dimension was contrasted between lower employment hours and improved wage 599 conditions. In addition, changes in fleet composition in this scenario mainly concerned the 600 decommissioning of 12-18 m trawlers that essentially operated in the north of the Bay of Biscay.

\section{Trade-offs achieved under the ITQ scenario}

602

603

604

605

606

607

608

609

610

611

612

613

614

615

617

618

619

620
In the ITQ scenario, supplier or buyer vessels depended on the marginal profit per $\mathrm{kg}$ of sole compared to the equilibrium price of the quota (see Figs. S6 and S7 in supplementary material). Depending on the year, between $39 \%$ and $46 \%$ of vessels leased out their individual quota of sole. The main suppliers were the sole netters and the specialized Nephrops trawlers, whereas the main buyers were the mixed netters and mixed bottom trawlers (Fig. 4b). Therefore, it appeared that highly specialized fleets had a lower willingness to pay than mixed fleets for which acquiring more quotas of sole increased the possibilities to catch a mix of species that included sole. Additionally, most vessels that leased out their quota of sole maintained a fishing activity on an "other metier" (these vessels are referred to as 'active lease-out vessels', as opposed to 'inactive lease-out vessels' that stopped their fishing activity completely).

As the final distribution of quota according to the ITQ option was essentially shifted from sole netters fleet to the trawlers fleets that had an exploitation pattern less selective of smaller individuals, the sole SSB recovered less quickly than in the co-management options (Table 2). Ecological sustainability proxies also indicated that ITQ would induce greater carbon footprint and impacts on habitats due to increased fishing effort by trawlers.

The management of quotas through ITQs appeared to be the most economically efficient option both in the short and long terms (Fig. 6a). As compared to the baseline, the ITQ scenario increased the gross operating surplus of the fishery by $69 \%$ during the phase of transition to MSY and by $33 \%$ the net present value of profits over the whole simulation period (Table 3). This significant increase was 
621 mainly driven by quota transfers from netters to trawlers that made it possible for less-specialized

622 fleets to increase their fishing effort and profits as acquiring additional quota also allowed them to 623 catch their by-products that represented a large part of their gross revenue. Economic impacts also 624 included increased inequality between vessels after the introduction of ITQs $(+25 \%$ in 2025). 625 According to the decomposition by fleet, it appeared that this was mainly due to an increase in 626 inequality within the sole netters and, to a lesser extent, within the mixed bottom trawlers (Fig. S9e 627 in supplementary material). It was also notable that inequality increased within all length classes (Fig. 628 S9f), which suggested that small-scale and large-scale vessels were all concerned with this issue in 629 the ITQ scenario.

630 As regards social sustainability indicators, the ITQ scenario leads to higher employment hours and 631 average yearly wage, but this is mostly related to a higher time at sea per year (Fig. 7; Table 4). In 632 fact, average hourly wage is lower than in the other scenarios. In addition, wage inequality greatly 633 increase due to distributional changes in the sole netters and mixed bottom trawlers fleets (see Fig. 634 S11e in supplementary material). In terms of territorial impacts, the larger-scale sole netters (> 10 $635 \mathrm{~m})$, which essentially operate in the south of the Bay of Biscay, are the predominant fleet segments 636 leasing out their quotas to Nephrops trawlers and mixed bottom trawlers. Therefore, the 637 introduction of ITQs could potentially induce a shift of activity in the fishery from the south to the 638 north of the Bay of Biscay as well as a change in the nature of the work itself since operating on a 639 trawler is quite different to operating on a netter. 


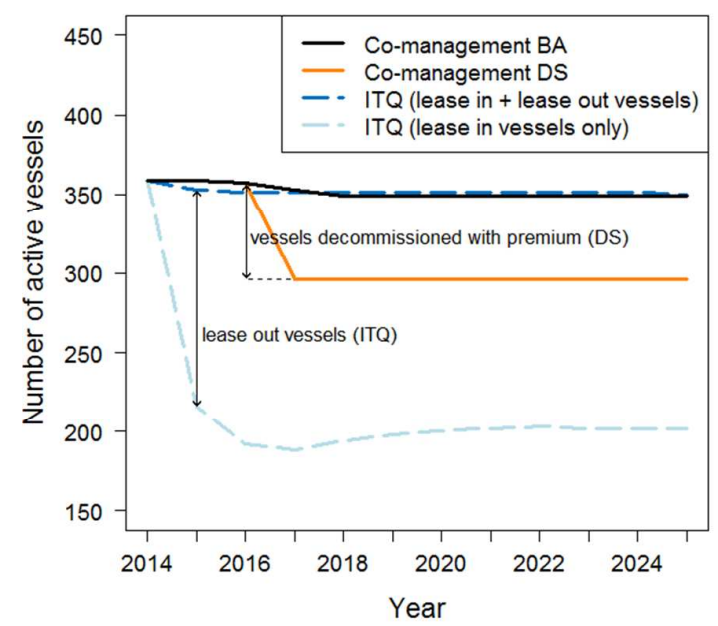

642 Fig. 3: Evolution of the fleet size in the Bay of Biscay sole fishery under the baseline (BA), 643 decommissioning scheme (DS), and individual transferable quota (ITQ) scenarios. In the ITQ scenario, 644 most vessels leasing out their quota of sole maintain a fishing activity on an 'other metier'; these vessels 645 correspond to the difference between the two dashed lines.

646

a

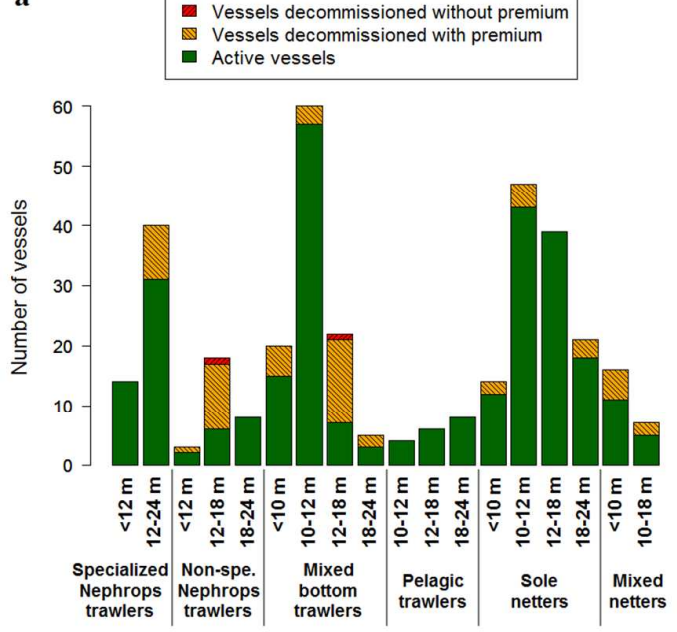

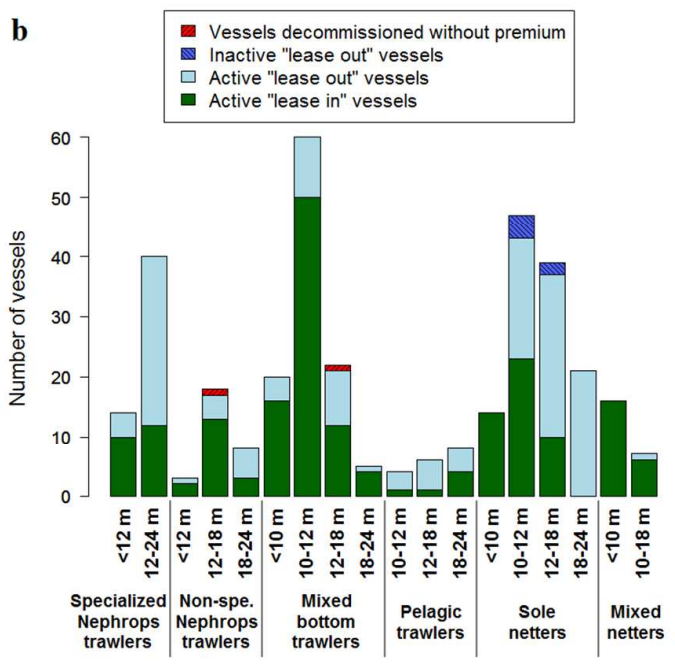

648

649

650

651

Fig. 4: Simulated fleet structure in the Bay of Biscay sole fishery in 2025 after (a) decommissioning scheme (DS scenario), (b) the introduction of individual transferable quotas (ITQ scenario). "Active leaseout vessels" are vessels leasing out their quota of sole while maintaining a fishing activity on an 'other metier', as opposed to "inactive lease-out vessels" that stop their fishing activity completely. 
652

a

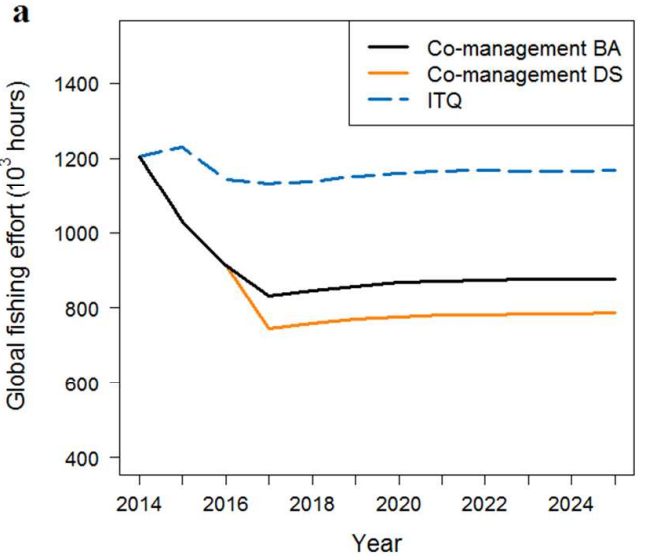

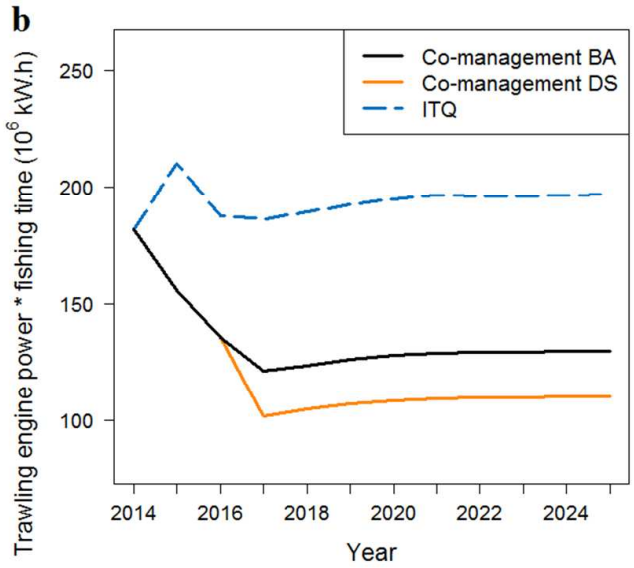

653

654

655

656

657

658

a

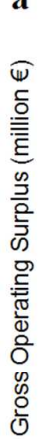

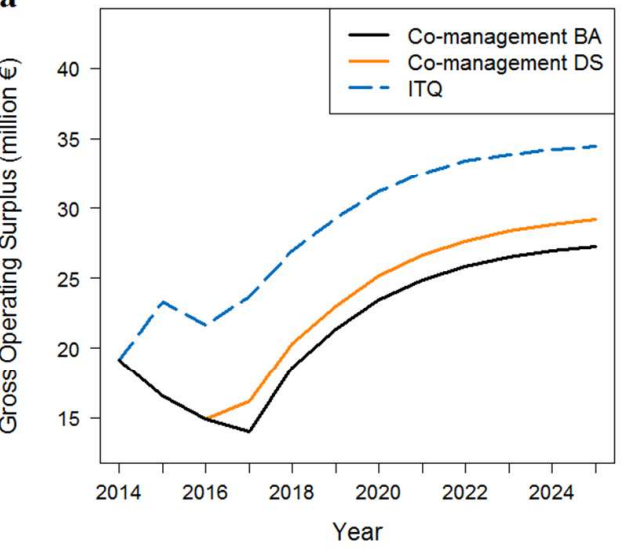

b

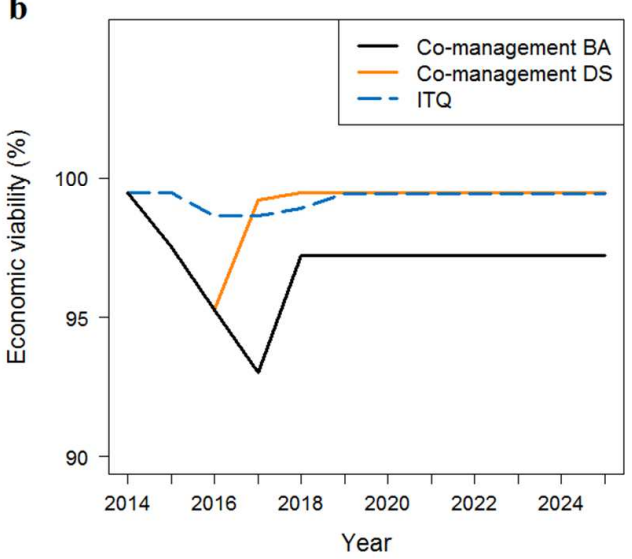

659

Fig. 5: Impacts on habitats: evolution of (a) fishing effort, (b) trawling "energy effort" in the Bay of Biscay sole fishery under the baseline (BA), decommissioning scheme (DS), and individual transferable quota (ITQ) scenarios.

660

Fig. 6: Evolution of (a) the total gross operating surplus, (b) economic viability index (\% vessels with gross

661 operating surplus $>0$ ) in the Bay of Biscay sole fishery under the baseline (BA), decommissioning scheme

662 (DS), and individual transferable quota (ITQ) scenarios.

663

664 

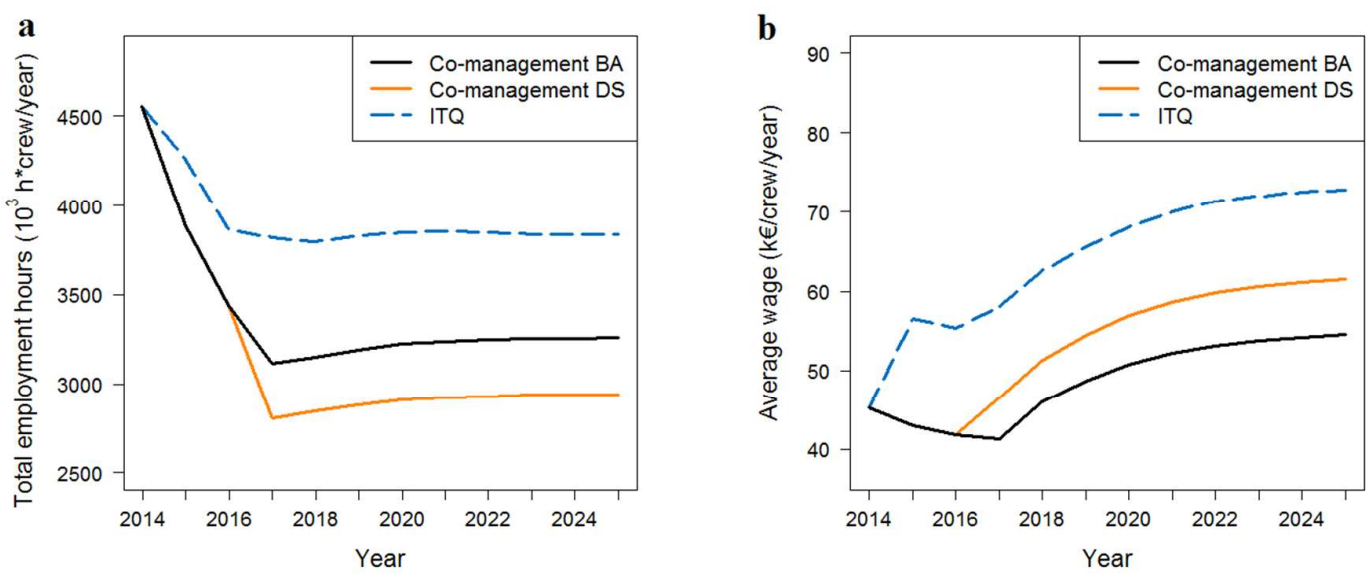

665
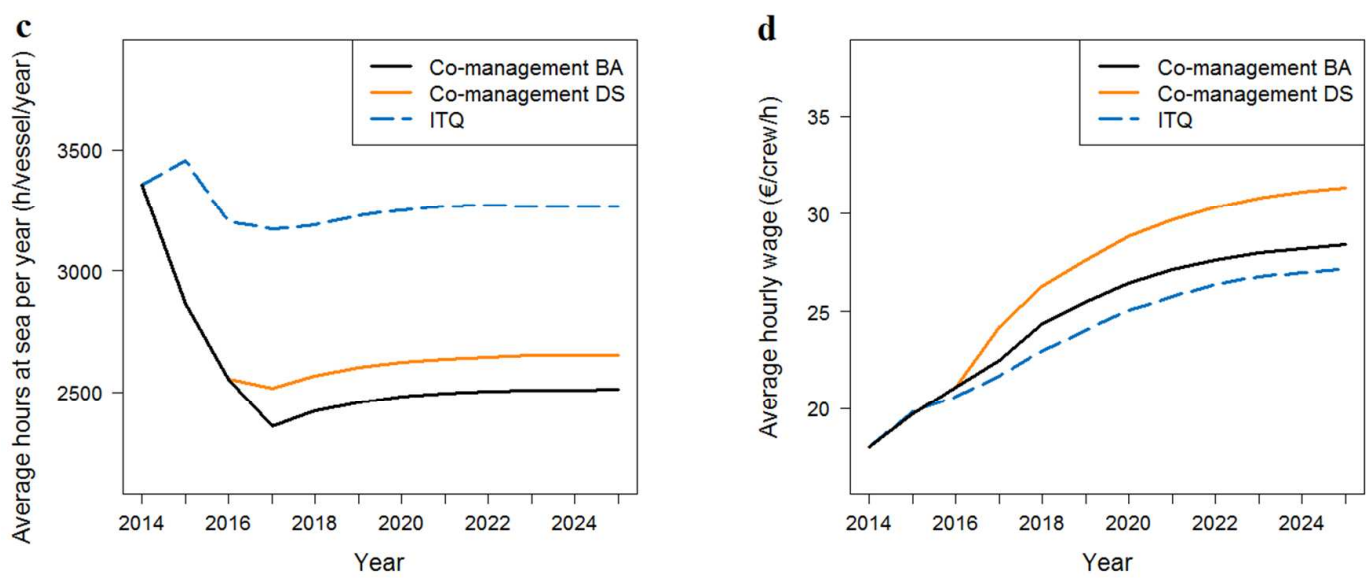

666

667 Fig. 7: Social impacts: evolution of (a) total employment hours in the fishery (hours at sea * crew), (b) 668 average crew remuneration per year, (c) average time at sea, (d) average hourly wage in the Bay of Biscay 669 sole fishery under the baseline (BA), decommissioning scheme (DS), and individual transferable quota 670 (ITQ) scenarios.

671

672

673 
Table 2: Assessment of ecological impacts of the decommissioning scheme (DS) and individual transferable quota (ITQ) scenarios evaluated against the baseline (BA). Numbers in the "DS vs BA" (resp.

676 "ITQ vs BA") columns are relative differences between indicator values for the DS scenario (resp. ITQ 677 scenario) compared to the baseline. SSB, spawning stock biomass.

\begin{tabular}{|c|c|c|c|c|c|}
\hline & \multirow{2}{*}{ Indicator } & \multicolumn{2}{|c|}{ Transition phase (2017) } & \multicolumn{2}{|c|}{ Long-term impacts (2025) } \\
\hline & & $\mathrm{DS} v s \mathrm{BA}$ & ITQ vs BA & $\mathrm{DS}$ vs $\mathrm{BA}$ & ITQ vs BA \\
\hline \multirow{3}{*}{ Stock status } & SSB sole $(t)$ & $+0 \%$ & $+0 \%$ & $+0 \%$ & $-8 \%$ \\
\hline & SSB Nephrops (t) & $+0 \%$ & $-3 \%$ & $+5 \%$ & $-9 \%$ \\
\hline & Landings sole (t) & $+0 \%$ & $+11 \%$ & $+0 \%$ & $+2 \%$ \\
\hline \multirow{2}{*}{$\begin{array}{l}\text { Impacts on } \\
\text { habitats } \\
\text { proxies }\end{array}$} & Fishing effort (h/year) & $-10 \%$ & $+36 \%$ & $-10 \%$ & $+33 \%$ \\
\hline & $\begin{array}{l}\text { Trawling energy effort } \\
\text { (kWh) }\end{array}$ & $-16 \%$ & $+53 \%$ & $-15 \%$ & $+52 \%$ \\
\hline $\begin{array}{l}\text { Carbon } \\
\text { footprint }\end{array}$ & $\begin{array}{c}\text { Fuel consumption } \\
\text { (L/year) }\end{array}$ & $-11 \%$ & $+41 \%$ & $-11 \%$ & $+38 \%$ \\
\hline
\end{tabular}

678
Table 3: Assessment of economic impacts of the decommissioning scheme (DS) and individual transferable quota (ITQ) scenarios evaluated against the baseline (BA). Numbers in the "DS vs BA" (resp. "ITQ vs BA") columns are relative differences between indicator values for the DS scenario (resp. ITQ scenario) compared to the baseline.

\begin{tabular}{lccccc}
\hline & Indicator & \multicolumn{2}{c}{ Transition phase (2017) } & \multicolumn{2}{c}{ Long-term impacts (2025) } \\
\cline { 2 - 6 } Profits & $\begin{array}{c}\text { Gross Operating } \\
\text { Surplus (€) }\end{array}$ & $+15 \%$ & $+69 \%$ & $+7 \%$ & $+27 \%$ \\
\hline $\begin{array}{l}\text { Economic } \\
\text { efficiency }\end{array}$ & $\begin{array}{c}\text { Cumulative net } \\
\text { present value of Net } \\
\text { Profit ( } € \text { ) }\end{array}$ & & & $+6 \%$ & $+33 \%$ \\
\hline $\begin{array}{l}\text { Economic } \\
\text { viability }\end{array}$ & $\begin{array}{c}\text { Gross Operating } \\
\text { Surplus > 0 (\% vessels) }\end{array}$ & $+7 \%$ & $+6 \%$ & $+2 \%$ & $+2 \%$ \\
\hline $\begin{array}{l}\text { Economic } \\
\text { inequality }\end{array}$ & $\begin{array}{c}\text { Theil index applied to } \\
\text { gross value of landings } \\
\text { (entropic distance } \\
\text { from perfect equality) }\end{array}$ & $-7 \%$ & $+23 \%$ & $-5 \%$ & $+25 \%$ \\
\hline
\end{tabular}

Table 4: Assessment of social impacts of the decommissioning scheme (DS) and individual transferable quota (ITQ) scenarios evaluated against the baseline (BA). Numbers in the "DS vs BA" (resp. "ITQ vs BA") columns are relative differences between indicator values for the DS scenario (resp. ITQ scenario) compared to the baseline.

\begin{tabular}{lccccc}
\hline & Indicator & \multicolumn{2}{c}{ Transition phase (2017) } & \multicolumn{2}{c}{ Long-term impacts (2025) } \\
\cline { 2 - 6 } & DS vs BA & ITQ vs BA & DS vs BA & ITQ vs BA \\
\hline $\begin{array}{l}\text { Employment } \\
\text { hours }\end{array}$ & $\begin{array}{c}\text { Crew * hours at sea } \\
\text { (h/year) }\end{array}$ & $-10 \%$ & $+23 \%$ & $-10 \%$ & $+18 \%$ \\
\hline $\begin{array}{c}\text { Average yearly wage } \\
\text { per crew (€/year) }\end{array}$ & $+13 \%$ & $+41 \%$ & $+13 \%$ & $+34 \%$ \\
\cline { 2 - 6 } & $\begin{array}{c}\text { Average hourly wage } \\
\text { (€/year) }\end{array}$ & $+8 \%$ & $-4 \%$ & $+10 \%$ & $-4 \%$ \\
\cline { 2 - 6 } & \begin{tabular}{c} 
Time at sea (h/year) \\
\cline { 2 - 6 }
\end{tabular} & $+7 \%$ & $+35 \%$ & $+6 \%$ & $+30 \%$ \\
\cline { 2 - 6 } $\begin{array}{c}\text { Wage inequality: Theil } \\
\text { index applied to yearly } \\
\text { wage per crew }\end{array}$ & $-12 \%$ & $+94 \%$ & $-5 \%$ & $+97 \%$ \\
\hline
\end{tabular}




\section{Sensitivity analysis}

690

691

692

693

694

695

696

697

698

699

700

701

702

703

704

705

706

707

708

709

710

711

712

713

We performed a sensitivity analysis to examine the effects of alterations in parameter values on the trade-offs achieved in each scenario. We focused on sensitivity to two key parameters, namely the profit-tradition weight $\alpha$ and the capital malleability parameter $\omega$, which are related to short-term and long-term dynamics, respectively. We considered $\alpha \in\{0.05,0.10,0.20,0.40,0.80\}$, the basecase parameter value being $\alpha=0.20$ which was set according to empirical estimates found in Marchal et al. (2013). The base-case value for the capital malleability parameter was $\omega=0.05$, and values tested ranged from $\omega=0$, in which case all vessels that had negative profits at the end of a time step exited the fishery, to $\omega=0.20$, which corresponded to a situation where investment was hardly reversible in terms of vessel resale value for capital and almost all vessels stayed in the fishery. Table 5 shows the effects of changes measured as deviation from base-case values of global fishing effort and gross operating surplus for each scenario separately. Additional results of the sensitivity analysis for fuel consumption and average hourly wage are provided in supplementary material (Figs. S12 and S13).

Overall, results of the simulations were robust to changes in values of parameters $\alpha$ and $\omega$, which showed that outcomes were more influenced by the management interventions defined in each scenario than by parameter values of the short- and long-term behaviour models. Observed changes in SSB and total landings were negligible (less than $1 \%$ deviation compared to base-case values) as the harvest control rule was not directly impacted by alterations of $\alpha$ and $\omega$. The most significant impacts on fishing effort and gross operating surplus were observed for greater alterations of $\alpha$ (Table 5). In the short term, the greater the weight given to profit in effort allocation, the more fishing effort and surplus increased. In the long term, individual efforts on "other metier" tended to converge towards either zero or maximum effort, yielding an equilibrium effort allocation. For values of $\alpha$ less than 0.1 , the rate at which effort allocation can shift from one metier to another was not high enough to reach equilibrium by the end of the simulation period, which explains why results 
714

715

716

717

718

719

720

721

722

723

724

725

726

727

observed for 2025 did not follow the same trend across all values of $\alpha$. Moreover, while changes in $\alpha$ affected outcomes in all three scenarios in the same way (depending on the indicator, either positive or negative deviations across all scenario), alterations of $\omega$ tended to have opposite effects on different scenarios (e.g. setting $\omega=0.20$ increased the fishing effort in the BA scenario and decreased it in the DS scenario). In addition, indicators were somewhat more sensitive to changes in $\alpha$ than in $\omega$, suggesting that short-term dynamics had more influence than long-term behaviours on the outcomes of the model (Figs. S12 and S13 in supplementary material). Nonetheless, the main driving forces behind the results appeared to be the different institutional designs of the management procedure as the trade-offs achieved in each scenario were not significantly changed by varying parameter values.

Table 5: Results of the sensitivity analysis, shown as deviations from base-case values of global fishing effort and gross operating surplus. $\alpha$ is the effort allocation parameter (profit-tradition weight); $\omega$ is the capital malleability parameter (disinvestment dynamics). Scenarios: BA, baseline; DS; decommissioning scheme; ITQ individual transferable quotas.

\begin{tabular}{|c|c|c|c|c|c|}
\hline \multirow{2}{*}{ Parameter values } & \multirow{2}{*}{ Scenario } & \multicolumn{2}{|c|}{$\begin{array}{l}\text { Fishing effort } \\
\text { (h/year) }\end{array}$} & \multicolumn{2}{|c|}{$\begin{array}{c}\text { Gross operating surplus } \\
(€ / \text { year })\end{array}$} \\
\hline & & 2017 & 2025 & 2017 & 2025 \\
\hline \multirow{3}{*}{$\begin{array}{l}(\alpha=0.20 ; \omega=0.05) \\
\text { base-case parameter values }\end{array}$} & Co-management BA & - & - & - & - \\
\hline & Co-management DS & - & - & - & - \\
\hline & ITQ & - & - & 一 & - \\
\hline \multirow{3}{*}{$(\alpha=0.05 ; \omega=0.05)$} & Co-management BA & $-3 \%$ & $-3 \%$ & $-7 \%$ & $-3 \%$ \\
\hline & Co-management DS & $-2 \%$ & $-3 \%$ & $-5 \%$ & $-2 \%$ \\
\hline & ITQ & $-2 \%$ & $-1 \%$ & $-5 \%$ & $-2 \%$ \\
\hline \multirow{3}{*}{$(\boldsymbol{\alpha}=\mathbf{0 . 1 0} ; \omega=0.05)$} & Co-management BA & $-2 \%$ & $-1 \%$ & $-4 \%$ & $-1 \%$ \\
\hline & Co-management DS & $-2 \%$ & $-1 \%$ & $-3 \%$ & $-1 \%$ \\
\hline & ITQ & $-2 \%$ & $0 \%$ & $-3 \%$ & $-1 \%$ \\
\hline \multirow{3}{*}{$(\alpha=0.40 ; \omega=0.05)$} & Co-management BA & $+2 \%$ & $-1 \%$ & $+6 \%$ & $-2 \%$ \\
\hline & Co-management DS & $+2 \%$ & $-1 \%$ & $+4 \%$ & $-2 \%$ \\
\hline & ITQ & $+2 \%$ & $-1 \%$ & $+4 \%$ & $-2 \%$ \\
\hline \multirow{3}{*}{$(\boldsymbol{\alpha}=\mathbf{0 . 8 0} ; \omega=0.05)$} & Co-management BA & $+1 \%$ & $-3 \%$ & $+6 \%$ & $-3 \%$ \\
\hline & Co-management DS & $+5 \%$ & $-3 \%$ & $+4 \%$ & $-5 \%$ \\
\hline & ITQ & $0 \%$ & $-7 \%$ & $+2 \%$ & $-6 \%$ \\
\hline \multirow{3}{*}{$(\alpha=0.20 ; \boldsymbol{\omega}=\mathbf{0 . 0 0})$} & Co-management BA & $-3 \%$ & $-3 \%$ & $+5 \%$ & $+2 \%$ \\
\hline & Co-management DS & $0 \%$ & $0 \%$ & $0 \%$ & $0 \%$ \\
\hline & ITQ & $-1 \%$ & $-1 \%$ & $+1 \%$ & $+1 \%$ \\
\hline \multirow{3}{*}{$(\alpha=0.20 ; \boldsymbol{\omega}=\mathbf{0 . 2 0})$} & Co-management BA & $+2 \%$ & $+3 \%$ & $-3 \%$ & $-2 \%$ \\
\hline & Co-management DS & $-1 \%$ & $-1 \%$ & $+1 \%$ & $0 \%$ \\
\hline & ITQ & $+1 \%$ & $+1 \%$ & $-1 \%$ & $-1 \%$ \\
\hline
\end{tabular}




\section{Discussion}

730 The results from our analysis indicate that, regardless of the catch-share design considered,

731 exploiting the Bay of Biscay sole at MSY would allow significant rebuilding of sole and Nephrops

732 stocks, which is consistent with findings from previous studies of the Bay of Biscay mixed fisheries

733 showing that committing to MSY management objectives could achieve considerable increase in SSB

734 (Guillen et al. 2013; STECF 2015). Nevertheless, the results of the simulations show differentiated

735 impacts between the three management options for the Bay of Biscay sole quotas and reveal trade-

736 offs between ecological, economic and social performances for each option. Interestingly, $70 \%$ of the

737 vessels decommissioned with premium in the DS scenario are vessels that actually lease in quota in

738 the ITQ scenario (see Table S21 in supplementary material). This result shows that the introduction of

739 ITQs would provide new possibilities to some vessels that would otherwise seize the opportunity of a

740 decommissioning premium in a system without transferability.

741 Similar to the bio-economic simulation analysis of decommissioning schemes developed by Guyader

742 et al. (2004), our model considers expectations of vessels over a discounting period but it is also

743 partly myopic in the sense that it does not integrate that vessels might expect improvement of the

744 net present value of their profits related to dissipation of congestion externalities. Despite this

745 drawback, the consequences of the decommissioning scheme simulated in this study are in line with

746 what has been observed in a number of buyback programs worldwide, including reduction of fishing

747 capacity, rebuilding of fish stocks, and increased economic efficiency (Holland et al. 1999; Groves and

748 Squires 2007). Notwithstanding improved performances induced by the scheme, the legitimacy of

749 subsidies granted to the fishing industry is debatable (CEC 2009). In our analysis, the total cost of the

750 decommissioning scheme presented in the DS scenario is 15.2 million euros. In comparison, annual

751 average fuel tax exemptions in the ITQ and DS scenarios are 26.1 and 17.5 million euros, respectively

752 (see Table S22 in supplementary material). Thus, the cost of the decommissioning scheme is less than

753 the difference between the ITQ and DS scenarios in fuel tax exemptions for two years. While this 
754

755

756

757

758

759

760

761

762

763

764

765

766

767

768

769

770

771

772

773

774

775

776

777

778

outcome is specific to our case study and do not apply to ITQ programs in general, this underscores the necessity to readdress the question of fuel tax exemptions that appear to be in contradiction with the need to reduce greenhouse gas emissions (Borrello et al. 2013). Although not investigated in this analysis, removing fuel tax exemptions in the ITQ scenario would presumably induce a shift of the quota demand toward less energy-consuming fleets, thereby improving the ecological performance of this option while reducing the level of indirect subsidies. Alternatively, introducing a limitation on quota transfers (e.g., Strauss 2013) from netters to trawlers in the design of the ITQ program would likely generate a similar effect.

The quota market simulated in this study is assumed to be a quota lease market whereas most ITQ programs also allow for permanent transfer of quota shares (Holland 2016). In turn, fleets' dynamics related to long-term behaviour of fishermen, i.e. changes in the level of capital investment, in a quota lease market situation are very limited and thus expected consequences of capacity adjustment were not fully assessed (Nøstbakken et al. 2011). Nevertheless, quota concentration phenomenon, which is one of the expected effects of implementation of an ITQ market as described in the literature (Squires et al. 1998; Arnason 2002) and underlined as a potential undesirable shift by a number of stakeholders fighting against implementation of ITQs, still occurs in a quota lease market (Pinkerton and Edwards 2009; Van Putten and Gardner 2010). Our simulations suggest that we could expect about $40 \%$ of vessels leasing out their quota, a result somewhat comparable to empirical evidence found in the literature (e.g., Hamon et al. (2009) and Abbott et al. (2010) observed $-35 \%$ of vessels in the Tasmanian rock lobster fishery and $-58 \%$ of vessels in the Bering Sea crab fisheries a few years after the introduction of ITQs, respectively).

Further developments could be considered as there are a number of assumptions and limitations that can potentially impede the realism of the model and scenarios as it stands. First, the parameterization of the initial allocation of catch shares was assumed proportional to the landings of reference, which could significantly differ from allocation keys used by POs in reality (Guyader et al. 
2014). The model could easily incorporate allocation rules that vary depending on the PO. The difficulty lies in the fact that these rules are not necessarily made public by POs and that they may change from one year to another depending on quota availability, which makes it challenging to include as input of the model. With the push to make quota allocation decisions more objective and transparent under Article 17 of the CFP (EU 2013), publicly available documentation on the methods and criteria used by POs for quota allocation may be demanded by authorities, thereby clarifying the quota management of POs. This information could be highly beneficial to the parameterization of the model and to the exploration of additional management scenarios. Then an interesting extension of the model presented in this paper would be to consider POs as agents influencing the dynamics of PO membership and endogenize voluntary changes of PO internal rules used for quota management and distribution among members (Guyader et al. 2014), which could be addressed through discretechoice modelling (Girardin et al. 2017).

Regarding the ITQ simulations presented in the analysis, the changes observed in the distribution of the quota among fleets and the significant increased fishing effort by vessels using non-selective gears are an inherent consequence of considering the implementation of a quota market for only one species in a mixed fishery context. Compared to fleets that are most dependent on sole, nonspecialized fleets have a higher willingness to pay for additional sole quota in order to be able to catch their by-product that represent a large part of their gross revenue (in reality, considering possible legal or illegal discarding practices may mitigate this result and alter the final distribution of the ITQ). To the contrary, sole netters that are very selective and dependent on sole have strong incentive to lease out their quota in our ITQ simulation. These results are highly dependent on the level of aggregation considered to model the joint production function and the single-species quota market represented in the model. In another way, Little et al. (2009) modelled a multispecies ITQ market and found significant declines in fishing effort, similar to experiences in many fisheries that have moved to ITQs (Grafton et al. 1996). 
804 In this study, the IAM model is used as a deterministic simulation tool to investigate alternative 805 quota management options for the transition to MSY in the Bay of Biscay sole fishery. This type of 806 approach where no stochasticity is applied is useful to identify the main drivers of the results in a 807 scenario analysis (Bartelings et al. 2015) and avoid situations where uncertainty makes it impossible 808 to discriminate the impacts of different management measures (Drouineau et al. 2006). The 809 sensitivity analysis indicates that our results are robust to changes in key parameter values related to 810 the behaviour of fishers. However, the model ignores resource variability and thus does not take into 811 account the consequences of uncertainty for achieving management objectives (Simons et al. 2014; 812 Punt et al. 2016). This issue was not addressed in the current study because of the high demand for 813 computational resources required by the combination of individual-based modelling and the Baranov 814 catch equation. Considering the necessity of using an individual-based model rather than a fleet815 based one to account for individual constraints on the behaviour of fishers, an alternative could be to 816 use a model with a simpler catch equation based solely on biomass (e.g. of the Schaeffer or Cobb817 Douglas type, rather than the Baranov catch equation where individual fishing mortality also 818 depends on total mortality), thereby ignoring interactions among vessels through the resource but 819 making it more feasible to introduce stochasticity in such an individual-based modelling approach 820 (Bastardie et al. 2013).

821 The paper demonstrates the value of an integrated simulation analysis for revealing trade-offs 822 between conflicting management objectives and informing fisheries management decisions. 823 Including institutional arrangements involving POs, such as the management of catch shares, 824 historical landings track records and internal reallocations, into the model allowed improved 825 comparability of PO-based co-management systems with market-based systems. Besides, simulating 826 the constraints and strategies of producers at the vessel level is also critical to better assess the 827 impacts of alternative management options. Although the results and policy implications are specific 828 to the Bay of Biscay sole fishery, this contribution demonstrates the feasibility of using such an 
approach in a real-world situation and will hopefully help improve the bio-economic methodologies

830 used for impact assessment of catch share designs and lead to broader applications.

831 Although informative in terms of quantifying the trade-offs between management objectives, the

832 analysis did not reveal any win-win-win scenario among those tested. This suggests that neither the

833 current institutions nor the introduction of an ITQ market are likely to make such solutions emerge.

834 As suggested by Burgess et al. (2017), the focus should be on the design of institutions, which should

835 be goal-oriented to maximize the chances of finding solutions that improve outcomes in all three

836 sustainability dimensions simultaneously. This underscores the relevance of integrating institutional

837 arrangements into bio-economic modelling frameworks to better understand the potential impacts

838 of management options and inform institutional design, although this does not ensure finding win-

839 win-win management options. To this end, the (co-)viability approach, aimed at identifying feasible

840 paths toward desirable objectives within a set of ecological, economic and social constraints, offers

841 interesting insights (Martinet et al. 2007; Péreau et al. 2012; Thébaud et al. 2014; Gourguet et al.

842 2016). However, bio-economic viability simulation modelling approaches have not fully integrated

843 the impacts of management systems on fishermen individual constraints yet, which could be an

844 interesting subject of research considering the push to develop integrated multi-objective tools.

\section{Acknowledgement}

846 This work was funded by the Région Bretagne and by EU FP7 SOCIOEC project (Grant no. 289192).

847 This financial support is gratefully acknowledged. Economic data provision was supported by a public

848 grant overseen by the French National Research Agency (ANR) as part of the "Investissements

849 d'Avenir" program (reference: ANR-10-EQPX-17 - Centre d'accès sécurisé aux données - CASD). The

850 authors are grateful to the associate editor and three anonymous reviewers for their helpful

851 comments. 
852

853

854

855

856

857

858

859

860

861

862

863

864

865

866

867

868

869

870

871

872

873

874

875

876

877

878

879

880

881

882

883

884

885

886

\section{References}

Abbott, J.K., Garber-Yonts, B., and Wilen, J.E. 2010. Employment and remuneration effects of IFQs in the Bering Sea/Aleutian Islands crab fisheries. Mar. Resour. Econ., 25(4), 333-354.

Allen, P.H., Wadsworth, E.J.K., and Smith, A.P. 2006. The relationship between recorded hours of work and fatigue in seafarers. In: Bust, P.D. (Ed.) Contemporary Ergonomics, Taylor and Francis, 546-548.

Allison, E.H., Ratner, B.D., Åsgård, B., Willmann, R., Pomeroy, R., and Kurien, J. 2012. Rights-based fisheries governance: from fishing rights to human rights. Fish Fish., 13(1), 14-29.

Aranda, M., and Murillas, A. 2015. Allocation of fishing possibilities, incentives and outcomes: Insights from Basque fishermen's organisations in Spain. Mar. Policy, 61, 171-178.

Arnason, R. 2002. A review of international experiences with ITQs. Annex to Future Options for UK Fishing Management, Report to the Department for the Environment, Food and Rural Affairs, CEMARE, University of Portsmouth, UK.

Autorité de la concurrence. 2015. Avis n¹5-A-19 du 16 décembre 2015 relatif aux effets sur la concurrence du mécanisme de répartition des quotas de pêche en France. Autorité de la concurrence, République Française, available online at http://www.autoritedelaconcurrence.fr/pdf/avis/15a19.pdf.

Bartelings, H., Hamon, K.G., Berkenhagen, J., and Buisman, F.C. 2015. Bio-economic modelling for marine spatial planning application in North Sea shrimp and flatfish fisheries. Environ. Mod. Soft., 74, 156-172.

Bastardie, F., Nielsen, J. R., and Miethe, T. 2013. DISPLACE: a dynamic, individual-based model for spatial fishing planning and effort displacement-integrating underlying fish population models. Can. J. Fish. Aquat. Sci., 71(3), 366-386.

Bellanger, M., Macher, C., and Guyader, O. 2016. A new approach to determine the distributional effects of quota management in fisheries. Fish. Res., 181, 116-126.

Beverton, R.J.H., and Holt, S.J. 1957. On the dynamics of exploited fish populations. Fishery Investigations, 2 (19), HMSO, Londres: 533 p.

Birkenbach, A.M., Kaczan, D.J., and Smith, M.D. 2017. Catch shares slow the race to fish. Nature, 544(7649), 223-226.

Borrello, A., Motova, A., and Dentes de Carvalho, N. 2013. Fuel subsidies in the EU fisheries sector. In: Policy Department B: Structural and Cohesion Policies. European Parliament, Italy.

Bunnefeld, N., Hoshino, E., and Milner-Gulland, E. J. 2011. Management strategy evaluation: a powerful tool for conservation?. Trends Ecol. Evol., 26(9), 441-447.

Burgess, M.G., Clemence, M., McDermott, G.R., Costello, C., and Gaines, S.D. 2017. Five rules for pragmatic blue growth. Mar. Policy (in press).

CEC. 2009. Commission of the European Communities. Green paper: reform of the Common Fisheries Policy. COM (2009)163 final CEC, Brussels.

Chu, C. 2009. Thirty years later: the global growth of ITQs and their influence on stock status in marine 
fisheries. Fish Fish., 10, 217-230.

888

889

890

891

892

893

894

895

896

897

898

899

900

901

902

903

904

905

906

907

908

909

910

911

912

913

914

915

916

917

918

919

920

921

Clark, C.W., Clarke, F.H., and Munro, G.R. 1979. The optimal exploitation of renewable resource stocks: problems of irreversible investment. Econometrica, 25-47.

Clark, C.W. 2006. The worldwide crisis in fisheries: economic models and human behavior. Cambridge University Press.

Coelho, M.F., Filipe, J.A., and Ferreira, M.A.M. 2011. Rights based management and the reform of the common fisheries policy: the debate. Int. J. Latest Trends Financ. Econ. Sci., 1(1).

Costello, C., Gaines, S.D., and Lynham, J. 2008. Can catch shares prevent fisheries collapse?. Science, 321(5896), 1678-1681.

Drouineau, H., Mahévas, S., Pelletier, D., and Beliaeff, B. 2006. Assessing the impact of different management options using ISIS-Fish: the French Merluccius merluccius-Nephrops norvegicus mixed fishery of the Bay of Biscay. Aquat. Living Resour., 19(1), 15-29.

European Commission (EC). 2006. Council regulation No 388/2006 of 23 February 2006 establishing a multiannual plan for the sustainable exploitation of the stock of sole in the Bay of Biscay. Official journal of the European Union L 65/1 7.3.2006.

European Commission (EC). 2009. European Commission Impact Assessment Guidelines, 15 January 2009, SEC(2009) 92.

European Union (EU). 2013. Regulation (EU) 1380/2013 of the European Parliament and the Council of the 11 of December 2013 on the Common Fisheries Policy. Official Journal of European Union, L354/22, 28.11.2013.

Frangoudes, K., and Bellanger, M. (2017). Fishers' opinions on marketization of property rights and the quota system in France. Mar. Policy, 80:107-112.

Fulton, E.A., Smith, A.D., Smith, D.C., and Johnson, P. 2014. An integrated approach is needed for ecosystem based fisheries management: insights from ecosystem-level management strategy evaluation. PLoS One, 9(1), e84242.

Garcia, D., Prellezo, R., Sanchez, S., Andres, M., and Santurtun, M. 2012. FLBEIA: A toolbox to conduct bioeconomic impact assessment of fisheries management strategies. In: ICES ASC, Bergen.

Girardin, R., Hamon, K.G., Pinnegar, J., Poos, J.J., Thébaud, O., Tidd, A., Vermard, Y., and Marchal, P. 2017. Thirty years of fleet dynamics modelling using discrete-choice models: What have we learned?. Fish Fish. 18(4):638-655.

Gourguet, S., Macher, C., Doyen, L., Thébaud, O., Bertignac, M., and Guyader, O. 2013. Managing mixed fisheries for bio-economic viability. Fish. Res., 140:46-62.

Gourguet, S., Thébaud, O., Jennings, S., Little, L.R., Dichmont, C.M., Pascoe, S., Deng, R.A., and Doyen, L. 2016. The cost of co-viability in the Australian northern prawn fishery. Environ. Model. Assess., 21(3), 371-389.

Gouvernement Français. 2009. Mémorandum français relatif à la réforme de la politique commune de la pêche. 
Paris. Available online at http://ec.europa.eu/ fisheries/reform/docs/france memo fr.pdf.

Grafton, R.Q. 1996. Individual transferable quotas: theory and practice. Rev. Fish Biol. Fisher., 6:5-20.

Grafton, R.Q., Arnason, R., Bjørndal, T., Campbell, D., Campbell, H.F., Clark, C.W., Connor, R., Dupont, D.P., Hannesson, R., Hilborn, R., Kirkley, J.E., Kompas, T., Lane, D.E., Munro, G.R., Pascoe, S., Squires, D., Steinshamn, S.I., Turris, B.R., and Weninger, Q. 2006. Incentive-based approaches to sustainable fisheries. Can. J. Fish. Aquat. Sci., 63(3), 699-710.

Groves, T., and Squires, D. 2007. Lessons from fisheries buybacks. In: Curtis, R., Squires, D. (Eds) Fisheries buybacks, Wiley-Blackwell, Ames, IA., 15-54.

Guillen, J., Macher, C., Merzéréaud, M., Bertignac, M., Fifas, S., and Guyader, O. 2013. Estimating MSY and MEY in multi-species and multi-fleet fisheries, consequences and limits: an application to the Bay of Biscay mixed fishery. Mar. Policy, 40: 64-74.

Guillen, J., Macher, C., Merzéréaud, M., Boncoeur, J., and Guyader, O. 2015. Effects of the Share Remuneration System on Fisheries Management Targets and Rent Distribution. Mar. Resour. Econ., 30(2), 123-138.

Guyader, O., Daures, F., and Fifas, S. 2004. A bioeconomic analysis of the impact of decommissioning programs: application to a limited-entry French scallop fishery. Mar. Resour. Econ., 19(2), 225-242.

Guyader, O., Metz, S., Macher, C., Merzereaud, M., Daures, F., Le Floc'h, P., and Bellanger, M. 2014. Selfimposed catch shares by French producers organizations. IIFET 2014, International Institute of Fisheries Economics \& Trade. 7-11 July 2014, Brisbane, Australia.

Hamon, K., Thébaud, O., Frusher, S., and Little, L.R. 2009. A retrospective analysis of the effects of adopting individual transferable quotas in the Tasmanian red rock lobster, Jasus edwardsii, fishery. Aquat. Living Resour., 22(4), 549-558.

Hilborn, R. 2007. Defining success in fisheries and conflicts in objectives. Mar. Policy, 31, 153-158.

Holland, D.S., Gudmundsson, E., and Gates, J. 1999. Do fishing vessel buyback programs work: a survey of the evidence. Mar. Policy, 23(1), 47-69.

Holland, D.S., and Sutinen, J.G. 1999. An empirical model of fleet dynamics in New England trawl fisheries. Can. J. Fish. Aquat. Sci., 56(2), 253-264.

Holland, D.S. 2010. Management Strategy Evaluation and Management Procedures: Tools for Rebuilding and Sustaining Fisheries, OECD Food, Agriculture and Fisheries Working Papers, No. 25, OECD Publishing. http://dx.doi.org/10.1787/5kmd77jhvkjf-en.

Holland, D.S. 2016. Development of the Pacific Groundfish Trawl IFQ Market. Mar. Resour. Econ. 31(4), 453464.

Hopkins, T., Bailly, D., Elmgren, R., Glegg, G., Sandberg, A., and Støttrup, J. 2012. A systems approach framework for the transition to sustainable development: potential value based on coastal experiments. Ecol. Soc. 17(3).

Høvdanum, A.S., Jensen, O.C., Petursdóttir, G., and Holmen, I.M. 2014. A review of fatigue in fishermen: a 
complicated and underprioritised area of research. Int. Maritime Health, 65(3), 166-172.

958

959

960

961

962

963

964

965

966

967

968

969

970

971

972

973

974

975

976

977

978

979

980

981

982

983

984

985

986

987

988

989

990

991

ICES. 2015. Report of the Working Group for the Bay of Biscay and the Iberian waters Ecoregion (WBGIE), 4-10 May 2015 Copenhagen, Denmark. Ref ICES CM/ACOM:11. 503 pp.

IREPA Onlus Coordinator. 2006. Evaluation of the capital value, investments and capital costs in the fisheries sector. $\mathrm{N}^{\circ} \mathrm{FISH} / 2005 / 03.203 p$.

Ives, M.C., Scandol, J.P., and Greenville, J. 2013. A bio-economic management strategy evaluation for a multispecies, multi-fleet fishery facing a world of uncertainty. Ecol. Modell., 256:69-84.

Jardine, S.L., and Sanchirico, J.N. 2012. Catch share programs in developing countries: A survey of the literature. Mar. Policy, 36(6):1242-1254.

Jennings, S., Dinmore, T.A., Duplisea, D.E., Warr, K.J., and Lancaster, J.E. 2001. Trawling disturbance can modify benthic production processes. J. Animal Ecol., 70(3), 459-475.

Journal Officiel de la République Française (JORF). 1997. Loi n 97-1051 du 18 novembre 1997 d'orientation sur la pêche maritime et les cultures marines. NOR: AGRX9600072L

Journal Officiel de la République Française (JORF). 2006. n³01 du 29 décembre 2006 page 19953 texte n¹04: Arrêté du 26 décembre 2006 établissant les modalités de répartition et de gestion collective des possibilités de pêche (quotas de captures et quotas d'effort de pêche) des navires français immatriculés dans la Communauté européenne. NOR: AGRM0602585A.

Journal Officiel de la République Française (JORF). 2014. n0299 du 27 décembre 2014 page 22407 texte $n^{\circ} 7$ : Décret n 2014-1608 du 26 décembre 2014 relatif à la codification de la partie réglementaire du livre IX du code rural et de la pêche maritime. NOR: DEVM1411755D.

Kaiser, M.J., Collie, J.S., Hall, S.J., Jennings, S., and Poiner, I.R. 2003. Impacts of fishing gear on marine benthic habitats. In: Sinclair, M., Valdimarsson, G. (Eds.), Responsible Fisheries in the Marine Ecosystem. FAO, Rome, pp. 197-217.

Larabi, Z., Guyader, O., Macher, C., and Daurès, F. 2013. Quota management in a context of non-transferability of fishing rights: the French case study. Ocean Coast. Manage. 84, 13-22.

Lebègue, D., Baumstark, L., and Hirztman, P. 2005. Révision du taux d'actualisation des investissements publics. Commissariat Général au Plan, France, 112 pp.

Le Floc'h, P., Murillas, A., Aranda, M., Daurès, F., Fitzpatrick, M., Guyader, O., Hatcher, A., Macher, C., and Marchal, P. 2015. The regional management of fisheries in European Western Waters. Mar. Policy, 51:375384.

Little, L.R., Punt, A.E., Mapstone, B.D., Begg, G.A., Goldman, B., and Williams, A.J. 2009. An agent-based model for simulating trading of multi-species fisheries quota. Ecol. Model., 220(23), 3404-3412.

Macher, C., Guyader, O., Talidec, C., and Bertignac, M. 2008. A cost-benefit analysis of improving trawl selectivity in the case of discards: The Nephrops norvegicus fishery in the Bay of Biscay. Fish. Res., 92(1): 76-89. 
992

993

994

995

996

997

998

999

1000

1001

1002

1003

1004

1005

1006

1007

1008

1009

1010

1011

1012

1013

1014

1015

1016

1017

1018

1019

1020

1021

1022

1023

1024

1025

1026

1027

Macher, C., Merzéréaud, M., Le Grand, C., Frésard, M., Bertignac, M., Fifas, S., Guyader, O., Biais, G., Lissardy, M., Jadaud, A., Le Corre, G., Frangoudes, K., Daurès, F., Van Iseghem, S., and Raveau, A. 2011. Groupe de travail partenarial pourla construction d'outils bio-économiques d'aide à la décision pour l'aménagement des pêcheries. Publications électroniques Amure, Série Rapports R-21-2011, 44.

Malvarosa, L., Motova, A., Doering, R., Murillas, A., Gothi, Macher, C., L., Lehuta, S., Nielsen, R., Araldson, G., and Accadia, P. 2015. Improvements in Impact Assessment for Fisheries Management: The Socioec Experience. XXII conference of the European Association of Fisheries Economist, April 28-30 2015, Salerno, Italy.

Marchal, P., Lallemand, P., and Stokes, K. 2009. The relative weight of traditions, economics, and catch plans in New Zealand fleet dynamics. Can. J. Fish. Aquat. Sci., 66(2), 291-311.

Marchal, P., Little, L.R., and Thébaud, O. 2011. Quota allocation in mixed fisheries: a bioeconomic modelling approach applied to the Channel flatfish fisheries. ICES J. Mar. Sci., 68(7):1580-1591.

Marchal, P., De Oliveira, J.A., Lorance, P., Baulier, L., and Pawlowski, L. 2013. What is the added value of including fleet dynamics processes in fisheries models?. Can. J. Fish. Aquat. Sci., 70(7), 992-1010.

Mardle, S., Pascoe, S., Boncoeur, J., Le Gallic, B., García-Hoyo, J.J., Herrero, I., Jimenez-Toribioc, R., Cortesc, C., Padillac, N., Nielsen, J.R., and Mathiesen, C. 2002. Objectives of fisheries management: case studies from the UK, France, Spain and Denmark. Mar. Policy, 26(6), 415-428.

Martinet, V., Thébaud, O., and Doyen, L. 2007. Defining viable recovery paths toward sustainable fisheries. Ecol. Econ., 64(2), 411-422.

Merino, G., Barange, M., Fernandes, J.A., Mullon, C., Cheung, W., Trenkel, V., and Lam, V. 2014. Estimating the economic loss of recent North Atlantic fisheries management. Prog. Oceanogr., 129, 314-323.

Merzéréaud, M., Macher, C., Bertignac, C., Frésard, M., Le Grand, C., Guyader, O., Daurès, F., and Fifas, S. 2011. Description of the Impact Assessment bio-economic Model for fisheries management (IAM), Amure Electronic Publications, Working Papers Series D-29-2011, 19 pp. Available at: http://www.umramure.fr/electro_doc_amure/D_29_2011.pdf.

Mongruel, R., Vanhoutte-Brunier, A., Fiandrino, A., Valette, F., Ballé-Béganton, J., Pérez Agúndez, J.A., Gallai, N., Derolez, V., Rousel, S., Lample, M., and Laugier, T. 2013. Why, how, and how far should microbiological contamination in a coastal zone be mitigated? An application of the systems approach to the Thau lagoon (France). J. Environ. Manage., 118, 55-71.

Murillas-Maza, A., and Andrés, M. 2016. Providing incentives for fishermen through rights-based comanagement systems. An impact-assessment on Basque fisheries. Mar. Policy, 70, 128-136.

Nielsen, J.R., Thunberg, E., Holland, D.S., Schmidt, J.O., Fulton, E.A., Bastardie, F., Punt, A.E, Allen, I., Bartelings, H., Bertignac, M., Bethke, E., Bossier, S., Buckworth, R., Carpenter, G., Christensen, A., Christensen, V., Da Rocha, J.M., Deng, R., Dichmont, C.M., Doering, R., Esteban, A., Fernandes, J.A., Frost, H., Garcia, D., Gasche, L., Gascuel, D., Gourguet, S., Groeneveld, R.A., Guillen, J., Guyader, O., Hamon, K., Hoff, A., Horbowy, J., Hutton, T., Lehuta, S., Little, L.R., Lleonart, J., Macher, C., Mackinson, S., Mahevas, S., Marchal, 
1028

1029

1030

1031

1032

1033

1034

1035

1036

1037

1038

1039

1040

1041

1042

1043

1044

1045

1046

1047

1048

1049

1050

1051

1052

1053

1054

1055

1056

1057

1058

1059

1060

1061

1062

1063

P., Mato-Amboage, R., Mapstone, B., Maynou, F., Merzéréaud, M., Palacz, A., Pascoe, S., Paulrud, A., Plaganyi, E., Prellezo, R., van Putten, E.I., Quaas, M., Ravn-Jonsen, L., Sanchez, S., Simons, S., Thébaud, O., Tomczak, M.T., Ulrich, C., Van Dijk, D., Vermard, Y., Voss, R., and Waldo, S. 2017. Integrated EcologicalSocioeconomic Fisheries Models - Evaluation, Review and Challenges for Implementation. Fish and Fisheries (in press).

Nøstbakken, L., Thébaud, O., and Sorensen, L-C. 2011. Investment Behaviour and Capacity Adjustment in Fisheries: A Survey of the Literature. Mar. Resour. Econ., 26, 95-117.

OECD. 2006. Financial support to fisheries: implications for sustainable development. OECD Publications, Paris, 2006.

O'Neill, F.G., and Ivanović, A. 2016. The physical impact of towed demersal fishing gears on soft sediments. ICES J. Mar. Sci., 73(1):5-14.

Péreau, J.C., Doyen, L., Little, L.R., and Thébaud, O. 2012. The triple bottom line: Meeting ecological, economic and social goals with individual transferable quotas. J. Environ. Econ. Manage., 63(3): 419-434.

Pinkerton, E., and Edwards, D.N. 2009. The elephant in the room: the hidden costs of leasing individual transferable quotas. Mar. Policy, 33:707-713.

Prellezo, R., Accadia, P., Andersen, J., Andersen, B., Buisman, E., Little, A., Nielsen, J., Poos, J.,Powell, J., and Röckmann, C. 2012. A review of EU bio-economic models for fisheries: The value of a diversity of models. Mar. Policy 36(2):423-431.

Punt, A.E., Butterworth, D. S., Moor, C.L., De Oliveira, J.A., and Haddon, M. 2016. Management strategy evaluation: best practices. Fish Fish., 17(2):303-334.

Quillérou, E., and Guyader, O. 2012. What is behind fleet evolution: a framework for flow analysis and application to the French Atlantic fleet. ICES J. Mar. Sci. 69, 1069-1077.

R Core Team. 2017. R: A language and environment for statistical computing. R Foundation for Statistical Computing, Vienna, Austria. URL https://www.R-project.org/.

Raveau, A., Macher, C., Mehault, S., Merzereaud, M., Le Grand, C., Guyader, O., Bertignac, M., Fifas, S., and Guillen Garcia, J. 2012. A bio-economic analysis of experimental selective devices in the Norway lobster (Nephrops norvegicus) fishery in the Bay of Biscay. Aquat. Living Resour., 25(3), 215-229

Simons, S.L., Bartelings, H., Hamon, K.G., Kempf, A.J., Döring, R., and Temming, A. 2014. Integrating stochastic age-structured population dynamics into complex fisheries economic models for management evaluations: the North Sea saithe fishery as a case study. ICES J. Mar. Sci., 71(7), 1638-1652.

Soulié, J.C., and Thébaud, O. 2006. Modeling fleet response in regulated fisheries: An agent-based approach. Math. Comput. Model., 44(5), 553-564.

Squires, D., Campbell, H., Cunningham, S., Dewees, C., Grafton, R.Q., Herrick, S.F., Kirkley, J., Pascoe, S., Salvanes, K., Shallard, B., Turris, B., and Vestergaard, N. 1998. Individual transferable quotas in multispecies fisheries. Mar. Policy, 22(2), 135-159.

STECF. 2015. Jardim, E., and Mosqueira, I. (Ed). 2015. Multiannual management plans SWW and NWW (STECF- 

15-04 \& 09). Publications Office of the European Union, Luxembourg, JRC Scientific and Policy reports. $84 \mathrm{pp}$.

Strauss, K. 2013. Catch Shares in Action: Danish Pelagic and Demersal Individual Transferable Quota Programs. Environmental Defence Fund.

1068

Thébaud, O., Innes, J., and Ellis, N. 2012. From anecdotes to scientific evidence? A review of recent literature 1069 on catch share systems in marine fisheries. Front. Ecol. Environ. 10(8), 433-437.

Thébaud, O., Ellis, N., Little, L.R., Doyen, L., and Marriott, R.J. 2014. Viability trade-offs in the evaluation of strategies to manage recreational fishing in a marine park. Ecol. Indicators, 46, 59-69.

1072

Ulrich, C., Wilson, D.C., Nielsen, J.R., Bastardie, F., Reeves, S.A., Andersen, B.S., and Eigaard, O.R. 2012. Challenges and opportunities for fleet-and métier-based approaches for fisheries management under the European Common Fishery Policy. Ocean Coast. Manage., 70, 38-47.

1075

UN. 2002. Report of the World Summit on Sustainable Development, Johannesburg, South Africa, 26 August-4 1076 September. Chapter I. Resolutions adopted by the Summit. 2. Plan of Johannesburg Plan of Implementation of the World Summit on Sustainable Development, IV. Protecting and managing the natural resource base of economic and social development, Paragraph 31.

1080

Van Hoof, L. 2013. Design or pragmatic evolution: applying ITQs in EU fisheries management. ICES J. Mar. Sci., 70(2):462-470.

1081 Van Putten, l., and Gardner, C. 2010. Lease quota fishing in a changing rock lobster industry. Mar. Policy, 34(5), 859-867. 